Article

\title{
Ionic Liquids Based on Oxidoperoxido-Molybdenum(VI) Complexes with a Chelating Picolinate Ligand for Catalytic Epoxidation
}

\author{
Željko Petrovski ${ }^{1, *},+\left(\mathbb{D}\right.$, Margarida M. Antunes ${ }^{2,+}{ }^{+}$, Ana Soraia Mendo ${ }^{1}$, Luís Cabrita ${ }^{1}$, \\ Isabel S. Gonçalves ${ }^{2}(D)$ Anabela A. Valente ${ }^{2, *(D)}$ and Luís C. Branco ${ }^{1, *}$ \\ 1 Cultural Heritage and Responsive Materials Group, CHARM, LAQV-REQUIMTE, \\ Departamento de Química, Faculdade de Ciências e Tecnologia, Universidade Nova de Lisboa, \\ 2829-516 Caparica, Portugal; a.mendo@campus.fct.unl.pt (A.S.M.); luis.cabrita@amorim.com (L.C.) \\ 2 CICECO-Aveiro Institute of Materials, Department of Chemistry, University of Aveiro, \\ Campus Universitário de Santiago, 3810-193 Aveiro, Portugal; margarida.antunes@ua.pt (M.M.A.); \\ igoncalves@ua.pt (I.S.G.) \\ * Correspondence: z.petrovski@fct.unl.pt (Ž.P.); atav@ua.pt (A.A.V.); 1.branco@fct.unl.pt (L.C.B.) \\ + These two authors contributed equally to this work.
}

Received: 11 November 2020; Accepted: 30 November 2020; Published: 2 December 2020

\begin{abstract}
Ionic oxidoperoxido-molybdenum(VI) complexes of the type [Cat][MoO( $\left.\left(\mathrm{O}_{2}\right)_{2}(\mathrm{pic})\right]$, with pic $=\mathrm{N}, \mathrm{O}$-chelated picolinate ligand and Cat $=$ monocation, were prepared in high yields $(82-95 \%)$ from the precursor complex $\left[\mathrm{H}_{3} \mathrm{O}\right]\left[\mathrm{MoO}\left(\mathrm{O}_{2}\right)_{2}\right.$ (pic)] via $[\mathrm{H}]^{+}$cation exchange for 1-ethyl-3-methylimidazolium $[\mathrm{EMIM}]^{+}$, 1-butyl-3-methylimidazolium [BMIM] ${ }^{+}$, 1-octyl-3-methylimidazolium [OMIM] ${ }^{+}, N$-cetylpyridinium $\left[\mathrm{C}_{16} \mathrm{Py}\right]^{+}$, and $\mathrm{N}$-methyl- $\mathrm{N}, \mathrm{N}, \mathrm{N}$-trioctylammonium [Aliquat] ${ }^{+}$. The structure and purity of the ionic compounds were assessed by ${ }^{1} \mathrm{H}$ and ${ }^{13} \mathrm{CNMR}$, FT-IR, and elemental analysis $(\mathrm{C}, \mathrm{H}, \mathrm{N})$, and the electrochemical properties were studied by differential pulse voltammetry (DPV) and cyclic voltammetry (CV). The [Cat] $\left[\mathrm{MoO}\left(\mathrm{O}_{2}\right)_{2}(\mathrm{pic})\right]$ compounds showed promising catalytic epoxidation activity based on the model reaction of cis-cyclooctene with tert-butyl hydroperoxide as oxidant. The type of cation influenced the physical state of the compound and the catalytic performance.
\end{abstract}

Keywords: ionic liquid complexes; oxidoperoxidomolybdenum; picolinate; catalysis; epoxidation

\section{Introduction}

Oxidodiperoxido-metal complexes of the type $\left[\mathrm{MO}\left(\mathrm{O}_{2}\right)_{2}(\mathrm{~L})_{n}\right]$ with $\mathrm{M}=\mathrm{Mo}, \mathrm{W}$ and $\mathrm{L}$ an organic Lewis base $(n=1,2)$, were discovered by Mimoun et al. [1] in 1969 and reported as stable complexes. These types of complexes were found to be effective oxidation catalysts with a broad substrate scope, such as olefins [2-8], alkyl benzenes [9,10], amines [11-13], alcohols [8,13-15], sulphides [13,16-24], and chalcogenides [25].

Neutral Mimoun type mononuclear complexes are well established catalysts for olefin epoxidation, as highlighted in several reviews $[6,7,26-29]$. These catalytic systems may use eco-friendly oxidants such as hydrogen peroxide [3,4,30-38] and tert-butyl hydroperoxide (TBHP) [8,30,35,39-45], and different types of solvents: catalyst $/ \mathrm{H}_{2} \mathrm{O}_{2}$ systems with organic solvents [3,4,30-34], water [35], ionic liquids $[36,37,46]$ or without solvent [38]; and catalyst/TBHP systems with an organic solvent [8,30,39-41,47-51], water [35], or without solvent [42-45].

As opposed to neutral Mimoun type mononuclear complexes, their ionic versions with the general formula $[\mathrm{Cat}]_{\mathrm{m}}\left[\mathrm{MoO}\left(\mathrm{O}_{2}\right)_{2}(\mathrm{~L})_{\mathrm{n}}\right](\mathrm{Cat}=$ cation, $m=1,2)$ have hardly been studied in the field of catalysis. In 1987, Dengel et al. [52] reported that the dianionic complex $\left[\mathrm{PPh}_{4}\right]_{2}\left[\mathrm{MoO}\left(\mathrm{O}_{2}\right)_{2}(\mathrm{~L})\right]$, with $\mathrm{L}=$ oxalate, was inactive as a catalyst for alkene epoxidation. In the 90's, the monoanionic 
complexes $\left[\mathrm{Bu}_{4} \mathrm{~N}\right]\left[\mathrm{MoO}\left(\mathrm{O}_{2}\right)_{2}(\mathrm{~L})\right],[\mathrm{CTA}]\left[\mathrm{MoO}\left(\mathrm{O}_{2}\right)_{2}(\mathrm{~L})\right](\mathrm{CTA}=$ cetyltrimethylammonium $)$ and $\left[\mathrm{H}_{3} \mathrm{O}\right]\left[\mathrm{MoO}\left(\mathrm{O}_{2}\right)_{2}(\mathrm{~L})\right]$, with $\mathrm{L}=$ picolinate $\mathrm{N}$-oxido, were reported as sources of oxygen (not as catalysts, i.e., the metal complexes were used in approximately stoichiometric amounts relative to the substrate) for oxidizing different glycols, alcohols, olefins, sulphides, sulfoxides and amines [53-59]. Later, in 2005, Maiti et al. [13] reported the anionic complex $\left[\mathrm{PPh}_{4}\right]\left[\mathrm{MoO}\left(\mathrm{O}_{2}\right)_{2}(\mathrm{QO})\right]$, with $\mathrm{QOH}=8$-quinolinol, as an active catalyst for the oxidation of alcohols, sulphides and amines using $\mathrm{H}_{2} \mathrm{O}_{2}$ as oxidant. However, in the same decade, Garah et al. [31,32,34,60] found that several monoanionic complexes of the type $[\mathrm{Cat}]\left[\mathrm{MoO}\left(\mathrm{O}_{2}\right)_{2}(\mathrm{~L})_{\mathrm{n}}\right]\left([\mathrm{Cat}]^{+}=\right.$tetraorganophosphonium type cation, and $\mathrm{L}=$ conjugated base of 2-hydroxybenzoic acid, benzoic acid [31], pyridine-2-carboxylic acid [32], or an oxime such as (hydroxyphenyl)ethenone [60], salicylaldoxime [34] and pyridine-2-carboxaldoxime [32]) were inactive as catalysts for olefin epoxidation using $\mathrm{H}_{2} \mathrm{O}_{2}$ as oxidant (co-additives were required for olefin epoxidation to occur).

More recently, Zare et al. [43,44] reported the first active olefin epoxidation catalyst of the type $[\mathrm{Cat}]_{\mathrm{m}}\left[\mathrm{MoO}\left(\mathrm{O}_{2}\right)_{2}(\mathrm{~L})_{\mathrm{n}}\right]$ with $\mathrm{L}=$ phox $=2$-(2'-hydroxyphenyl)-5,6-dihydro-1,3-oxazine $\left([\mathrm{Cat}]^{+}\right.$was not specified). In these studies, TBHP was used as oxidant, as opposed to the previous catalytic epoxidation studies using the ionic complexes with $\mathrm{H}_{2} \mathrm{O}_{2}$ as oxidant.

In this work, ionic complexes of the type $[\mathrm{Cat}]\left[\mathrm{MoO}\left(\mathrm{O}_{2}\right)_{2}(\mathrm{~L})\right]$ were synthesized, characterized, and tested as epoxidation catalysts with TBHP, without the need of additional co-catalysts or co-additives. A set of compounds was prepared possessing $\mathrm{L}=2$-picolinate (pic) and [Cat $]^{+}=\mathrm{N}$-cetylpyridinium

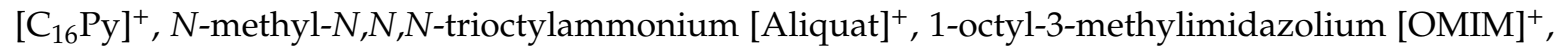
1-butyl-3-methylimidazolium [BMIM] ${ }^{+}$or 1-ethyl-3-methylimidazolium [EMIM] ${ }^{+}$. These compounds and their synthetic precursor $\left[\mathrm{H}_{3} \mathrm{O}\right]\left[\mathrm{MoO}\left(\mathrm{O}_{2}\right)_{2}\right.$ (pic)] were tested as catalysts in the model epoxidation reaction of cis-cyclooctene/TBHP, at $70{ }^{\circ} \mathrm{C}$, giving up to quantitative epoxide yield at $3 \mathrm{~h}$ reaction.

\section{Materials and Methods}

Commercially available reagents were used for the syntheses of the complexes and catalytic tests. The anion exchange resin Amberlite IRA-400-OH (hydroxide ion-exchange capacity $=1.4$ meq. $\mathrm{mL}^{-1}$ ) was purchased from Supelco. The synthetic precursor $\left[\mathrm{H}_{3} \mathrm{O}\right]\left[\mathrm{MoO}\left(\mathrm{O}_{2}\right)_{2}(\right.$ pic) $]$ (pale yellow solid) was prepared by adapting a known procedure [61]. With the exception of ethanol used in the syntheses (96\%, Valente \& Ribeiro, Belas, Portugal), which was distilled before use, all other chemicals were used as received from commercial suppliers: molybdenum(VI) oxide (99.5\%, Alfa Aesar, Kandel, Germany), hydrogen peroxide (30\% w/v, Panreac), [EMIM][Br], [OMIM] [Br] and [BMIM][Cl] (all >98\%, Solchemar), $N$-cetylpyridinium chloride (>98\%, BDH), Aliquat 336 (>97\%, Sigma-Aldrich, Algés, Portugal), cis-cyclooctene (95\% Alfa Aesar, Kandel, Germany), 2-trans-octene (97\%, Sigma-Aldrich, Algés, Portugal), cyclododecene (96\%, mixture cis/trans, Aldrich, Algés, Portugal), tert-butyl hydroperoxide (5.5 M in decane, Aldrich, Algés, Portugal), 30\% aqueous hydrogen peroxide (Riedel-de-Haën), anhydrous $\alpha, \alpha, \alpha$-trifluorotoluene ( $\geq 99 \%$, Sigma-Aldrich, Algés, Portugal), acetonitrile (gradient grade, Honeywell), 1,2-dichloroethane (99\%, Aldrich, Algés, Portugal), and undecane ( $\geq 99 \%$, Aldrich, Algés, Portugal) as the internal standard.

${ }^{1} \mathrm{H}$ and ${ }^{13} \mathrm{C}$ NMR spectra were recorded on a Bruker AMX400 spectrometer at room temperature unless specified otherwise. Chemical shifts are reported downfield in parts per million (ppm). Melting points were determined using a Stuart Scientific apparatus. The IR spectra were measured on a Perkin Elmer 683 and are reported as either in $\mathrm{NaCl}$, pellets or neat. The elemental analyses were performed on a CHNS Series Thermo Finnigan-CE Instruments Flash EA 1112, under standard conditions (combustion reactor at $900{ }^{\circ} \mathrm{C}, \mathrm{GC}$ column furnace at $65^{\circ} \mathrm{C}$, multiseparation SS GC column, He flow of $130 \mathrm{~mL} / \mathrm{min}$,

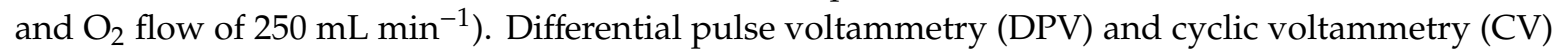
were used for electrochemical analyses. Electrochemical cells and glass were pre-washed with a mixture of sulphuric acid and 30\% hydrogen peroxide (1:1). All the material was then washed with Mili-Q water and ethanol, oven-dried at $80^{\circ} \mathrm{C}$, and then cooled to room temperature and stored in a desiccator prior to use. HPLC grade acetonitrile was dried over calcium hydride, distilled, and kept 
under an argon atmosphere. The supporting electrolyte was tetrabutylammonium perchlorate (TBAP), which was pre-dried and stored in a desiccator. Each sample was vacuum-dried, and dissolved in $0.1 \mathrm{M}$ TBAP in MeCN directly in the electrochemical cell, in order to obtain a $1 \mathrm{mM}$ solution of the analyte. The solutions were deoxygenated under argon flow. A potentiostat/galvanostat Autolab model 12 (Echo-Chemie) was used coupled to a computer with GPES 4.9 software. The electrochemical cell was made of quartz and contained the following electrodes: (a) working electrode of platinum, internal diameter $1.6 \mathrm{~mm}$ (BIAS Inc, MF-2000); (b) auxiliary electrode of platinum wire, and (c) standard calomel reference electrode (SCE) in $3 \mathrm{M} \mathrm{KCl}$. CV experiments were performed in the potential range -1.2 to $+2.0 \mathrm{~V}$ and DPV in the range -1.5 to $2.0 \mathrm{~V}$ with a modulation time of $0.05 \mathrm{~s}$, scan rate of $50 \mathrm{mV} / \mathrm{s}$, interval time of $0.5 \mathrm{~s}$, step potential of $0.006 \mathrm{~V}$, modulation amplitude of $0.06 \mathrm{~V}$, and the voltammograms were recorded after 5 cycles.

$\left[\mathrm{H}_{3} \mathrm{O}\right]\left[\mathrm{MoO}\left(\mathrm{O}_{2}\right)_{2}\right.$ (pic)] (1). Molybdenum trioxide $(1.5 \mathrm{~g}$, $10.4 \mathrm{mmol})$ was dissolved in $30 \%$ hydrogen peroxide $(15 \mathrm{~mL})$ at 40 to $45{ }^{\circ} \mathrm{C}$ overnight. The solution obtained was cooled to $0{ }^{\circ} \mathrm{C}$. A solution of picolinic acid $(1.28 \mathrm{~g}, 10.4 \mathrm{mmol})$ in water $(2 \mathrm{~mL})$ was then added slowly. The reaction mixture was left overnight in the fridge to form a light yellow precipitate. This solid was separated by filtration and vacuum-dried to provide $\left[\mathrm{H}_{3} \mathrm{O}\right]\left[\mathrm{MoO}\left(\mathrm{O}_{2}\right)_{2}\right.$ (pic)] as a yellow powder $(2.6 \mathrm{~g}, 80 \%)$. Spectral data were as described in refs $[27,62]$-FT-IR $\left(\mathrm{cm}^{-1}\right) \tilde{v}=3480$ (vs, broad), [OH]; 1685 (s), $\left[(\mathrm{C}=\mathrm{O})_{\mathrm{as}}\right] ; 973(\mathrm{~s}),[\mathrm{Mo}=\mathrm{O}] ; 850(\mathrm{~s}),[\mathrm{O}-\mathrm{O}] ; 572(\mathrm{~s}),\left[\left(\mathrm{MoO}_{2}\right)_{\mathrm{as}}\right]$ and $542(\mathrm{~m}),\left[\left(\mathrm{MoO}_{2}\right)_{\mathrm{sym}}\right]$.

[EMIM][MoO( $\left.\left(\mathrm{O}_{2}\right)_{2}(\mathrm{pic})\right](2)$. [EMIM][Br] $(0.136 \mathrm{~g}, 0.71 \mathrm{mmol})$ was dissolved in distilled water $(10 \mathrm{~mL})$ and passed through an anion exchange column loaded with Amberlite IRA-400(OH) $(2.6 \mathrm{~mL}$; 5 eq., flux rate $\left.8 \mathrm{BV} \mathrm{h}^{-1}\right)$. The resultant [EMIM][OH] solution was slowly added to a $0.1 \mathrm{M}$ aqueous solution (10 mL) of $\mathbf{1}$ ( $1 \mathrm{mmol} ; 1.4$ eq.). The reaction mixture was stirred at room temperature for $1 \mathrm{~h}$, and subsequently extracted several times using dichloromethane. The combined extracts were subjected to solvent evaporation followed by vacuum-drying at room temperature, giving the pure product as a yellow powder $(0.28 \mathrm{~g}, 96 \%)$. m.p. $82-86{ }^{\circ} \mathrm{C} .{ }^{1} \mathrm{H} \mathrm{NMR}\left(400.13 \mathrm{MHz}, \mathrm{CDCl}_{3}\right): \delta(\mathrm{ppm})=9.10(\mathrm{~s}, 1 \mathrm{H})$; $8.16(\mathrm{~d}, 1 \mathrm{H}, \mathrm{J}=4.4 \mathrm{~Hz}) ; 8.03(\mathrm{~d}, 1 \mathrm{H}, \mathrm{J}=7.5 \mathrm{~Hz}) ; 7.84(\mathrm{t}, 1 \mathrm{H}, \mathrm{J}=7.5 \mathrm{~Hz}) ; 7.38-7.31(\mathrm{~m}, 3 \mathrm{H}) ; 4.34(\mathrm{q}, 2 \mathrm{H}$, $\mathrm{J}=7.3 \mathrm{~Hz}) ; 4.02(\mathrm{~s}, 3 \mathrm{H}) ; 1.57(\mathrm{t}, 3 \mathrm{H} ; \mathrm{J}=7.3 \mathrm{~Hz}) .{ }^{13} \mathrm{C} \mathrm{NMR}\left(100.63 \mathrm{MHz}, \mathrm{CDCl}_{3}\right): \delta(\mathrm{ppm})=169.51$; $147.51 ; 145.29 ; 139.16 ; 136.69 ; 127.40 ; 124.52 ; 123.81 ; 121.92 ; 45.58 ; 36.66 ; 15.49$. Selected FT-IR $\left(\mathrm{cm}^{-1}\right)$ $\tilde{v}=3144(\mathrm{~m}), 3107(\mathrm{~m}), 3067(\mathrm{~s}), 1684(\mathrm{vs}), 1600(\mathrm{~s}), 1572(\mathrm{~s}), 1474(\mathrm{~m}), 1444(\mathrm{~m}), 1426(\mathrm{~m}), 1375,1324(\mathrm{vs})$, 1291(s), 1257(m), 1173(s), 1149(s), 1045(m), 944(vs), 870(s), 857(vs), 772, 758(s), 711(s), 696(s), 648(m), 633(m), 581(m), 530(m), 446(m). Elemental analysis calcd. (\%) for $\mathrm{C}_{12} \mathrm{H}_{15} \mathrm{MoN}_{3} \mathrm{O}_{7}: \mathrm{C} 35.22 ; \mathrm{H}$ 3.69; N 10.27; found: C 35.50; H 3.57; N 9.91.

[BMIM][MoO(O $\left.\mathrm{O}_{2}\right)_{2}$ (pic)] (3). [BMIM][Cl] $(0.25 \mathrm{~g}, 1.43 \mathrm{mmol})$ was dissolved in distilled water $(20 \mathrm{~mL})$ and passed through an anion exchange column loaded with Amberlite IRA-400(OH) $(5.2 \mathrm{~mL}$; 5 eq., flux rate $8 \mathrm{BV} \mathrm{h}^{-1}$ ). The resultant [BMIM][OH] solution was slowly added to a $0.1 \mathrm{M}$ aqueous solution ( $20 \mathrm{~mL}$ ) of 1 ( $2 \mathrm{mmol} ; 1.4 \mathrm{eq}$.). The reaction mixture was stirred at room temperature for $1 \mathrm{~h}$ and then extracted several times using dichloromethane. The combined extracts were subjected to solvent evaporation followed by vacuum-drying at room temperature, giving the pure product as a yellow viscous liquid $(0.51 \mathrm{~g}, 82 \%)$. m.p. $44-52{ }^{\circ} \mathrm{C} .{ }^{1} \mathrm{H}$ NMR $\left(400.13 \mathrm{MHz}, \mathrm{CDCl}_{3}\right)$ : $\delta(\mathrm{ppm})=9.17(\mathrm{~s}, 1 \mathrm{H}) ; 8.16(\mathrm{~d}, 1 \mathrm{H} ; \mathrm{J}=3.6 \mathrm{~Hz}) ; 8.02(\mathrm{~d}, 1 \mathrm{H} ; \mathrm{J}=7.6 \mathrm{~Hz}) ; 7.84(\mathrm{t}, 1 \mathrm{H}, \mathrm{J}=7.2 \mathrm{~Hz}) ; 7.38-7.33$ $(\mathrm{m}, 3 \mathrm{H}) ; 4.26(\mathrm{t}, 2 \mathrm{H}, \mathrm{J}=7.2 \mathrm{~Hz}) ; 4.02(\mathrm{~s}, 3 \mathrm{H}), 1.87(\mathrm{t}, 2 \mathrm{H}, \mathrm{J}=7.2 \mathrm{~Hz}) ; 1.36(\mathrm{q}, 2 \mathrm{H}, \mathrm{J}=7.2 \mathrm{~Hz}) ; 0.93(\mathrm{t}, 3 \mathrm{H}$, $\mathrm{J}=7.2 \mathrm{~Hz}) .{ }^{13} \mathrm{C}$ NMR $\left(101.63 \mathrm{MHz}, \mathrm{CDCl}_{3}\right): 169.52 ; 147.54 ; 145.30 ; 139.12 ; 137.11 ; 127.37 ; 124.50 ; 123.74$; 122.13; 50.12; 36.66; 32.19; 19.61; 13.56. Selected FT-IR $\left(\mathrm{cm}^{-1}\right) \tilde{v}=3437(\mathrm{vs}), 3166(\mathrm{~m}), 3123(\mathrm{~m}), 2956$, 2934, 2872, 1678(vs), 1651(s), 1601(s), 1577(m), $1469(\mathrm{~m}), 1442(\mathrm{~m}), 1382,1334(\mathrm{~s}), 1286(\mathrm{~m}), 1257,1238$, 1159, 1111, 1158(m), 1091, 1042, 951(s), 873(m), 863(s), 833(m), 823, 757(m), 711, 694, 650, 622, 583, 525, 443. Elemental analysis calcd. (\%) for $\mathrm{C}_{14} \mathrm{H}_{19} \mathrm{MoN}_{3} \mathrm{O}_{7}$ : $\mathrm{C} 38.46 ; \mathrm{H} 4.38 ; \mathrm{N}$ 9.61; found: $\mathrm{C} 38.52 ; \mathrm{H}$ 4.17; N 9.34 .

[OMIM] $\left[\mathrm{MoO}\left(\mathrm{O}_{2}\right)_{2}\right.$ (pic)] (4). [OMIM][Br] $(0.165 \mathrm{~g}, 0.71 \mathrm{mmol})$ was dissolved in distilled water $(10 \mathrm{~mL})$ and passed through an anion exchange column loaded with Amberlite IRA-400(OH) $(2.6 \mathrm{~mL}$; 5 eq., flux rate $8 \mathrm{BV} \mathrm{h}^{-1}$ ). The resultant [OMIM][OH] solution was slowly added to a $0.1 \mathrm{M}$ aqueous 
solution (10 mL) of $\mathbf{1}$ ( $1 \mathrm{mmol}$; $1.4 \mathrm{eq}$.). The reaction mixture was stirred at room temperature for $1 \mathrm{~h}$ and then extracted several times using dichloromethane. The combined extracts were subjected to solvent evaporation followed by vacuum-drying at room temperature, giving the pure product as an amorphous solid (0.32 g, 91\%). m.p. $106-108^{\circ} \mathrm{C} .{ }^{1} \mathrm{H} \mathrm{NMR}\left(400.13 \mathrm{MHz}, \mathrm{CDCl}_{3}\right): \delta(\mathrm{ppm})=9.17(\mathrm{~s}, 1 \mathrm{H})$; $8.19(\mathrm{~d}, 1 \mathrm{H} ; \mathrm{J}=4.8 \mathrm{~Hz}) ; 8.03(\mathrm{~d}, 1 \mathrm{H}, \mathrm{J}=7.4 \mathrm{~Hz}) ; 7.83(\mathrm{t}, 1 \mathrm{H}, \mathrm{J}=7.4 \mathrm{~Hz}) ; 7.37-7.21(\mathrm{~m}, 3 \mathrm{H}) ; 4.27(\mathrm{t}, 2 \mathrm{H}$, $\mathrm{J}=6.8 \mathrm{~Hz}) ; 4.05(\mathrm{~s}, 3 \mathrm{H}) ; 1.90(\mathrm{t}, 2 \mathrm{H}, \mathrm{J}=6.8 \mathrm{~Hz}) ; 1.62(\mathrm{~s}, 2 \mathrm{H}) ; 1.32-25(\mathrm{~m}, 8 \mathrm{H}) ; 0.86(\mathrm{t}, 3 \mathrm{H}, \mathrm{J}=6.4 \mathrm{~Hz})$. ${ }^{13} \mathrm{C} \mathrm{NMR}\left(101.63 \mathrm{MHz}, \mathrm{CDCl}_{3}\right): \delta(\mathrm{ppm})=169.47 ; 147.54 ; 145.27 ; 139.09 ; 136.83 ; 127.33 ; 124.48 ; 123.82 ;$ $122.18 ; 50.42 ; 36.65 ; 31.80 ; 30.29 ; 29.12 ; 29.03 ; 26.37 ; 22.70 ; 14.19$. Selected FT-IR $\left(\mathrm{cm}^{-1}\right) \tilde{v}=3561,3146(\mathrm{~m})$, 3108(m), 2926(m), 2855(m), 1681(s), 1602(m),1572(m), 1469(m), 1328(m), 1290(m), 1257, 1240, 1159(m), 1092, 1045(m), 1023(m), 946(s), 860(s), 762(m), 735(m), 711(m), 696(m), 651(m), 623(m), 583(m), 530, 482. Elemental analysis calcd. (\%) for $\mathrm{C}_{18} \mathrm{H}_{27} \mathrm{MoN}_{3} \mathrm{O}_{7}$ : C 43.82; $\mathrm{H} 5.52 ; \mathrm{N}$ 8.52; found: $\mathrm{C} 44.02 ; \mathrm{H}$ 5.48; N 8.47.

$\left[\mathrm{C}_{16} \mathrm{Py}\right]\left[\mathrm{MoO}\left(\mathrm{O}_{2}\right)_{2}\right.$ (pic)] (5). [ $\left.\mathrm{C}_{16} \mathrm{Py}\right][\mathrm{Cl}](0.240 \mathrm{~g}, 0.71 \mathrm{mmol})$ was dissolved in distilled water $(10 \mathrm{~mL})$ and passed through an anion exchange column loaded with Amberlite IRA-400(OH) $(2.5 \mathrm{~mL}$; 5 eq., flux rate $8 \mathrm{BV} \mathrm{h}^{-1}$ ). The resultant $N$-cetylpyridinium hydroxide solution was slowly added to a $0.1 \mathrm{M}$ aqueous solution $(10 \mathrm{~mL})$ of $\mathbf{1}$ (1 mmol; $1.4 \mathrm{eq}$.). The reaction mixture was stirred at room temperature for $1 \mathrm{~h}$. The product was filtered using a Hirsh funnel, washed with distilled water, and vacuum-dried at room temperature to give the pure product as a pale-yellow powder $(0.39 \mathrm{~g}$, 91\%). m.p. 89-92 ${ }^{\circ} \mathrm{C} .{ }^{1} \mathrm{H}$ NMR $\left(400.13 \mathrm{MHz}, \mathrm{CDCl}_{3}\right): \delta(\mathrm{ppm})=8.97(\mathrm{~d}, 2 \mathrm{H}, \mathrm{J}=4.0 \mathrm{~Hz}) ; 8.46-8.44$ (m, 1H); 8.16-8.02 (m, 4H); 7.83 (bs, 1H); 7.36 (bs, 1H); 4.75 (bs, 2H); $2.04(\mathrm{bs}, 2 \mathrm{H}) ; 1.62$ (bs, 2H); 1.33-1.23 $(\mathrm{m}, 24 \mathrm{H}) ; 0.88$ (bs, 3H). ${ }^{13} \mathrm{C} \mathrm{NMR}\left(100.63 \mathrm{MHz}, \mathrm{CDCl}_{3}\right): \delta(\mathrm{ppm})=169.43 ; 147.54 ; 145.27 ; 144.76 ; 139.05$; 128.72; 127.32; 124.47; 62.79; 32.06; 31.84; 31.06; 29.82; 29.66; 29.50; 29.15; 26.28, 22.82; 14.26. Selected FT-IR $\left(\mathrm{cm}^{-1}\right) \tilde{v}=3447(\mathrm{~m}), 3118(\mathrm{~m}), 3081(\mathrm{~m}), 3053(\mathrm{~m}), 2916(\mathrm{vs}), 2850(\mathrm{~s}), 1684(\mathrm{vs}), 1654,1629(\mathrm{~m}), 1603(\mathrm{~m})$, 1498(w), 1483(m), 1471(m), 1458(m), 1443, 1329(s), 1295(m), 1259(m), 1152(s), 1047(m), 947(vs), 861(vs), 781, 760, 712(m), 695(m), 649, 585. Elemental analysis calcd. (\%) for $\mathrm{C}_{27} \mathrm{H}_{42} \mathrm{MoN}_{2} \mathrm{O}_{7}: \mathrm{C} 53.82 ; \mathrm{H} 7.03$; N 4.65; found: C 54.02; H 7.03; N 4.59.

[Aliquat][MoO(O $\left.\mathrm{O}_{2}\right)_{2}$ (pic)] (6). [Aliquat][Cl] $(0.285 \mathrm{~g}, 0.71 \mathrm{mmol})$ was dissolved in ethanol $(10 \mathrm{~mL})$ and passed through an anion exchange column loaded with Amberlite IRA-400(OH) $(2.6 \mathrm{~mL} ; 5$ eq., flux rate $\left.8 \mathrm{BV} \mathrm{h}^{-1}\right)$. The resultant [Aliquat] $[\mathrm{OH}$ ] solution was slowly added to a $0.1 \mathrm{M}$ aqueous solution $(10 \mathrm{~mL})$ of $\mathbf{1}(1 \mathrm{mmol} ; 1.4$ eq.). The reaction mixture was stirred at room temperature for $1 \mathrm{~h}$, and then subjected to solvent evaporation. The concentrated solution was diluted with distilled water and subsequently extracted several times using chloroform. The combined extracts were subjected to solvent evaporation followed by vacuum-drying at room temperature, giving the pure product as a yellow coloured, room temperature ionic liquid (RTIL) $(0.45 \mathrm{~g}, 95 \%) .{ }^{1} \mathrm{H}$ NMR $\left(400.13 \mathrm{MHz}, \mathrm{CDCl}_{3}\right): \delta(\mathrm{ppm})=8.20(\mathrm{~d}, 1 \mathrm{H}, \mathrm{J}=4.4 \mathrm{~Hz}) ; 8.02(\mathrm{~d}, 1 \mathrm{H}, \mathrm{J}=7.7 \mathrm{~Hz}) ; 7.80(\mathrm{t}, 1 \mathrm{H}, \mathrm{J}=7.7 \mathrm{~Hz}) ;$ $7.33(\mathrm{~m}, 1 \mathrm{H}) ; 3.31(\mathrm{t}, 6 \mathrm{H}, \mathrm{J}=8.4 \mathrm{~Hz}) ; 3.18(\mathrm{~s}, 3 \mathrm{H}) ; 1.60-1.45(\mathrm{~m}, 6 \mathrm{H}) ; 1.35-1.25(\mathrm{~m}, 30 \mathrm{H}), 0.87(\mathrm{t}, 9 \mathrm{H}$, $\mathrm{J}=6.8 \mathrm{~Hz}) .{ }^{13} \mathrm{C}$ NMR $\left(101.63 \mathrm{MHz}, \mathrm{CDCl}_{3}\right): \delta(\mathrm{ppm})=169.38 ; 147.78 ; 145.29 ; 138.79 ; 127.11 ; 124.35$; $61.98 ; 48.77 ; 31.99 ; 31.78 ; 29.56 ; 29.52 ; 29.40 ; 29.21 ; 29.16 ; 26.44 ; 22.79 ; 22.72 ; 22.53 ; 14.21$. Selected FT-IR $\left(\mathrm{cm}^{-1}\right) \tilde{v}=2924(\mathrm{~s}), 2854(\mathrm{~m}), 1679(\mathrm{~s}), 1602(\mathrm{~m}), 1468(\mathrm{~m}), 1443,1327(\mathrm{~m}), 1290,1256,1155,1044,947(\mathrm{~s})$, 859(s), 761, 710(m), 696, 651(m), 583(m), 500(s). Elemental analysis calcd. (\%) for $\mathrm{C}_{31} \mathrm{H}_{58} \mathrm{MoN}_{2} \mathrm{O}_{7} \cdot 2 \mathrm{H}_{2} \mathrm{O}$ : C 52.98; H 8.89; N 3.99; found: C 53.10; H 8.55; N 3.61.

Catalytic epoxidation tests: The catalytic tests were carried out at $70{ }^{\circ} \mathrm{C}$ under air in a closed borosilicate batch reactor with $5 \mathrm{~mL}$ capacity, equipped with a V-shaped magnetic stirring bar and a valve for sampling. Typically, the reactor was loaded with $1 \mathrm{~mol} \%$ molybdenum complex relative to the substrate: the substrate $(1.8 \mathrm{mmol})$, the oxidant $(2.74 \mathrm{mmol})$ and a solvent $(1 \mathrm{~mL})$. The solvents used were $\alpha, \alpha, \alpha$-trifluorotoluene (TFT), acetonitrile and 1,2-dichloroethane (DCE). The loaded reactor was immersed in a thermostatically controlled oil bath heated at $70^{\circ} \mathrm{C}$, with a stirring rate of $1000 \mathrm{rpm}$; this was taken as the initial instant of the epoxidation reaction.

Prior to sampling and analysis of freshly prepared samples, the reactor was quenched in cold water, and the reaction mixture was subjected to centrifugation (3500 rpm). The catalytic 
reactions were monitored using an Agilent 7820A GC equipped with a capillary column (HP-5 $30 \mathrm{~m} \times 0.320 \mathrm{~mm} \times 0.25 \mathrm{~mm}$ ), a flame ionization detector, and undecane was used as internal standard. Product identification was carried out using a GC-MS (Trace GC 2000 series (Thermo Quest CE instruments)-DSQ II mass detector (Thermo Scientific)) equipped with an Agilent J\&W DB1 capillary column (DB-1 MS, $30 \mathrm{~m} \times 0.25 \mathrm{~mm} \times 0.25 \mathrm{~mm}$ ), with He as carrier gas. TOF were based on catalytic results at $6 \mathrm{~h}$ reaction. Conversion was calculated using the formula $100 \times[(($ initial molar concentration of $\mathrm{Cy})-($ molar concentration of $\mathrm{Cy}$ at time $\mathrm{t})) /($ initial molar concentration of $\mathrm{Cy})]$ and cyclooctene oxide $(\mathrm{CyO})$ selectivity was calculated using the formula $100 \times[($ molar concentration of $\mathrm{CyO}$ at time $\mathrm{t}) /(($ initial molar concentration of $\mathrm{Cy})-($ molar concentration of $\mathrm{Cy}$ at time $\mathrm{t}))]$.

\section{Results and Discussion}

\subsection{Characterization of the Ionic Complexes}

Five ionic compounds of the type $[\mathrm{Cat}]\left[\mathrm{MoO}\left(\mathrm{O}_{2}\right)_{2}(\mathrm{pic})\right]$ with pic $=$ picolinate and [Cat ${ }^{+}=$ $\mathrm{N}$-containing organic cation (pyridinium, imidazolium or ammonium), were prepared according to Scheme 1. Specifically, the precursor $\left[\mathrm{H}_{3} \mathrm{O}\right]\left[\mathrm{MoO}\left(\mathrm{O}_{2}\right)_{2}\right.$ (pic) $](\mathbf{1})$ was reacted with a hydroxide of the desired monocation $\left([\mathrm{Cat}] \mathrm{OH}\right.$, with $[\mathrm{Cat}]^{+}=[\mathrm{EMIM}]^{+},[\mathrm{BMIM}]^{+},[\mathrm{OMIM}]^{+},\left[\mathrm{C}_{16} \mathrm{Py}^{+},[\text {Aliquat }]^{+}\right)$, giving the desired [Cat] $\left[\mathrm{MoO}\left(\mathrm{O}_{2}\right)_{2}\right.$ (pic)] (2-6) in good yields (82-95\%). For these reactions, the base [Cat] $\mathrm{OH}$ was prepared from the corresponding salt [Cat]X using the anion exchange resin Amberlite IRA 400-OH. The physical state of the ionic complexes is dependent on the type of cation. It is observed a solid organic salt for $[\mathrm{Cat}]^{+}=\mathrm{OMIM}^{+}(4)$ (m.p. 106-108 ${ }^{\circ} \mathrm{C}$ ); ionic liquids (ILs) for [Cat ${ }^{+}=[\mathrm{EMIM}]^{+}$ (2), $[\mathrm{BMIM}]^{+}(3)$, and $\left[\mathrm{C}_{16} \mathrm{Py}\right]^{+}(5)$ (the melting points of the complexes were $82-86{ }^{\circ} \mathrm{C}, 44-52{ }^{\circ} \mathrm{C}$ and $89-92{ }^{\circ} \mathrm{C}$, respectively) and room temperature ionic liquid (RTIL) for [Cat ${ }^{+}=$[Aliquat $^{+}(6)$ [63].

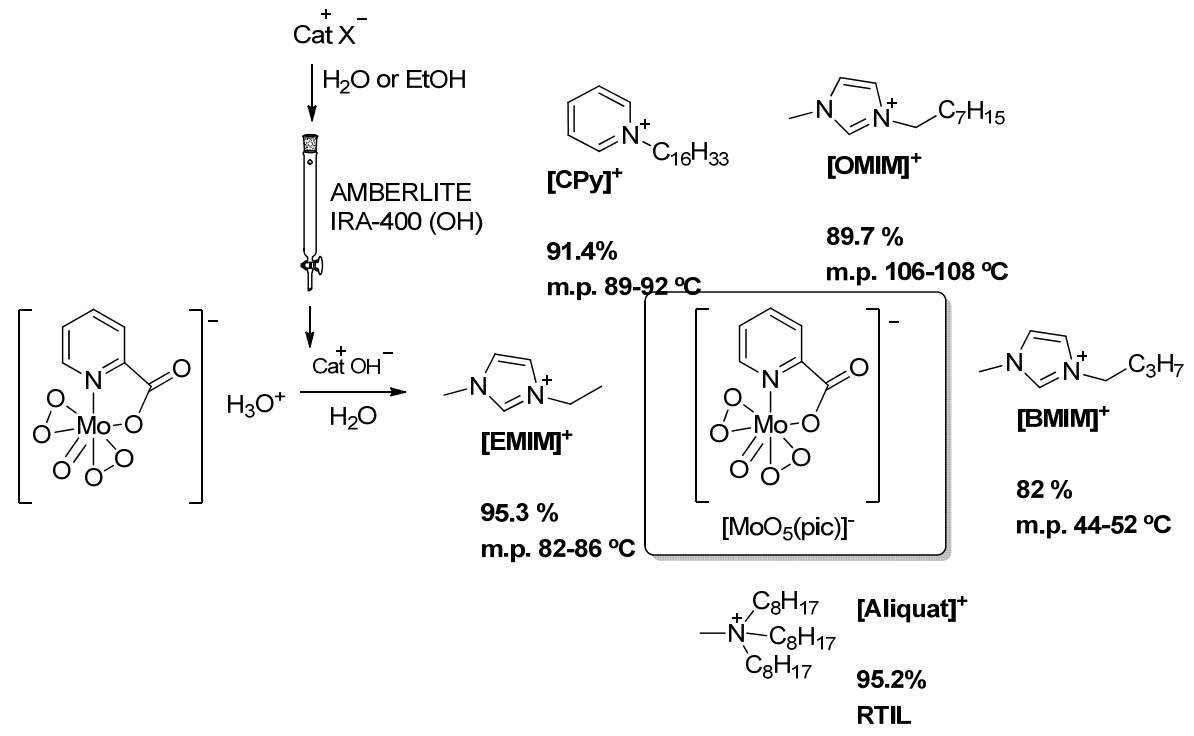

Scheme 1. Synthesis route leading to the complexes [Cat] $\left[\mathrm{MoO}\left(\mathrm{O}_{2}\right)_{2}(\mathrm{pic})\right]$.

The chemical structures and purities of compounds 2-6 were checked by ${ }^{1} \mathrm{H}-\mathrm{NMR},{ }^{13} \mathrm{C}-\mathrm{NMR}$ and FT-IR spectroscopies, and elemental analysis $(\mathrm{C}, \mathrm{H}, \mathrm{N})$. Experimental elemental analysis data is in good agreement with the calculated values. The characteristic IR bands of $\mathbf{1}$ and its [Cat] $\left[\mathrm{MoO}\left(\mathrm{O}_{2}\right)_{2}\right.$ (pic)] derivatives are very similar with respect to the carbonyl group $\left(v(\mathrm{C}=\mathrm{O})_{\mathrm{as}}=1685\right.$ vs. $1678-1684$ $\left.\mathrm{cm}^{-1}\right)$, but are slightly shifted with respect to the oxido and peroxido groups in the $\operatorname{MoO}\left(\mathrm{O}_{2}\right)_{2}$ moiety $\left(v(\mathrm{Mo}=\mathrm{O})=973\right.$ vs. $944-950 \mathrm{~cm}^{-1} ; v(\mathrm{O}-\mathrm{O})=850$ vs. $854-862 \mathrm{~cm}^{-1} ; v\left(\mathrm{Mo}\left(\mathrm{O}_{2}\right)_{2}\right)_{\mathrm{as}}=572 \mathrm{vs}$. $582-585 \mathrm{~cm}^{-1}$ and $v\left(\mathrm{Mo}\left(\mathrm{O}_{2}\right)_{2}\right)_{\text {sym }}=542$ vs. $\left.525-550 \mathrm{~cm}^{-1}\right)[27,62]$. None of the compounds exhibited the characteristic band of the carbonyl group attributed to the free picolinic acid (2-pyridinecarboxylic 
acid) at $1722 \mathrm{~cm}^{-1}$ [64]. All spectral data (IR, ${ }^{1} \mathrm{H}$, and ${ }^{13} \mathrm{C}$ NMR), as well as elemental analysis $(\mathrm{C}, \mathrm{H}$, $\mathrm{N}$ ), suggested pure compounds containing an anionic metal complex.

The electrochemical properties of the ionic complexes were studied by differential pulse voltammetry (DPV) and cyclic voltammetry (CV) (Figure 1) using as reference SCE (standard calomel electrode in $3 \mathrm{M} \mathrm{KCl}$ ). In general, the voltammograms in DPV showed one predominate oxidation peak at approximately $1.45 \mathrm{~V}$, while the corresponding wave in $\mathrm{CV}$ is irreversible.

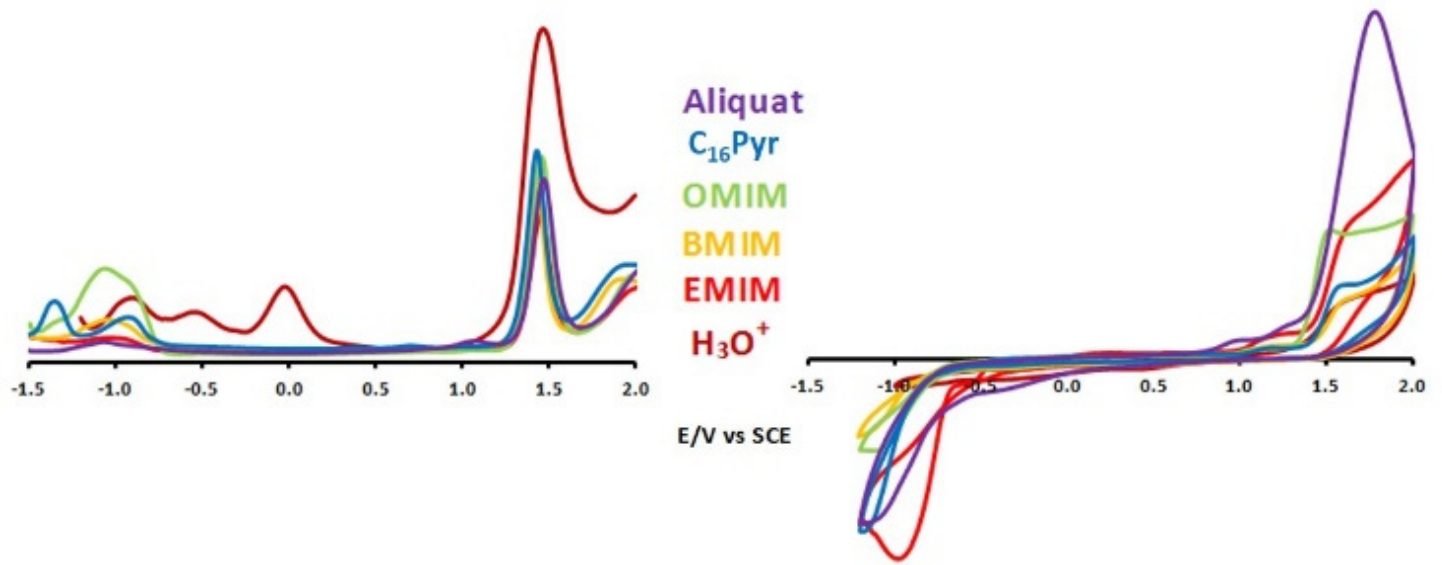

Figure 1. Voltammograms of the $[\mathrm{Cat}]\left[\mathrm{MoO}\left(\mathrm{O}_{2}\right)_{2}(\right.$ pic) $]$ compounds with $[\mathrm{Cat}]^{+}=\left[\mathrm{H}_{3} \mathrm{O}\right]^{+},[\mathrm{EMIM}]^{+}$, $\left[\mathrm{BMIM}^{+},[\mathrm{OMIM}]^{+},\left[\mathrm{C}_{16} \mathrm{Py}\right]^{+}\right.$or $[\text {Aliquat }]^{+}:$on the left voltammograms by DPV; on the right voltammograms by $\mathrm{CV}$.

The additional oxidation wave at ca. $+2.0 \mathrm{~V}$ was detected for most complexes. In general, the complexes exhibited the $\mathrm{Ep}_{2}$ reduction peak between -0.89 and $-1.07 \mathrm{~V}$. The compounds with $\left[\mathrm{C}_{16} \mathrm{Py}\right]^{+}$and $\left[\mathrm{H}_{3} \mathrm{O}\right]^{+}$cations exhibited one $(-1.36 \mathrm{~V})$ or two $(-0.55 \mathrm{~V}$ and $-0.02 \mathrm{~V})$ additional reduction peaks, respectively (Table 1). Overall, the DPV and CV results suggested that the variation of the cation structure does not significantly affect the electrochemical profile of the anionic complex.

Table 1. Potential of oxidation and reduction (V) of the $[\mathrm{Cat}]\left[\mathrm{MoO}\left(\mathrm{O}_{2}\right)_{2}\right.$ (pic) $]$ compounds.

\begin{tabular}{|c|c|c|c|c|c|c|}
\hline 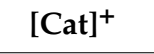 & $E p_{1}$ & $E p_{2}$ & $\mathrm{Ep}_{3}$ & $\mathrm{Ep}_{4}$ & $E p_{5}$ & $\mathrm{Ep}_{6}$ \\
\hline [Aliquat] $^{+}$ & & -1.07 & & & +1.47 & +2.07 \\
\hline$\left[\mathrm{C}_{16} \mathrm{Py}\right]^{+}$ & -1.36 & -0.93 & & & +1.43 & +1.97 \\
\hline [OMIM] $^{+}$ & & -1.05 & & & +1.45 & +1.99 \\
\hline [BMIM] $^{+}$ & & -1.04 & & & +1.43 & +1.90 \\
\hline [EMIM] $^{+}$ & & & & & +1.45 & +1.98 \\
\hline$\left[\mathrm{H}_{3} \mathrm{O}\right]^{+}$ & & -0.89 & -0.55 & -0.02 & +1.46 & n.d. ${ }^{1}$ \\
\hline
\end{tabular}

\section{2. cis-Cyclooctene Catalytic Epoxidation}

The complexes [Cat] $\left[\mathrm{MoO}\left(\mathrm{O}_{2}\right)_{2}\right.$ (pic) $]$ with [Cat ${ }^{+}=\mathrm{N}$-containing organic cation, and the synthetic precursor with [Cat] ${ }^{+}=\mathrm{H}_{3} \mathrm{O}^{+}$, were studied as catalysts in the model epoxidation reaction of Cy with TBHP as oxidant, at $70{ }^{\circ} \mathrm{C}$ (Figure 2 and Table 2). The TBHP: Cy molar ratio was 1.6, and [Cat] $\left[\mathrm{MoO}\left(\mathrm{O}_{2}\right)_{2}\right.$ (pic)] was added in an amount equivalent to $1 \mathrm{~mol} \%$ of molybdenum relative to $\mathrm{Cy}$. For all compounds already prepared, the turnover number (TON) was greater than unity (13-100 $\mathrm{mol}_{\mathrm{Cy}} \mathrm{mol}_{\mathrm{Mo}}{ }^{-1}$ ), and up to $100 \%$ Cy conversion was reached (Figure 2a). Without catalyst, conversion was negligible. Cyclooctene oxide $(\mathrm{CyO})$ was the main product formed in up to $100 \%$ yield (Figure $2 b)$. These results demonstrate the ability of the catalysts $[\mathrm{Cat}]\left[\mathrm{MoO}\left(\mathrm{O}_{2}\right)_{2}\right.$ (pic)] to trigger the epoxidation process with TBHP and without requiring co-catalysts. 

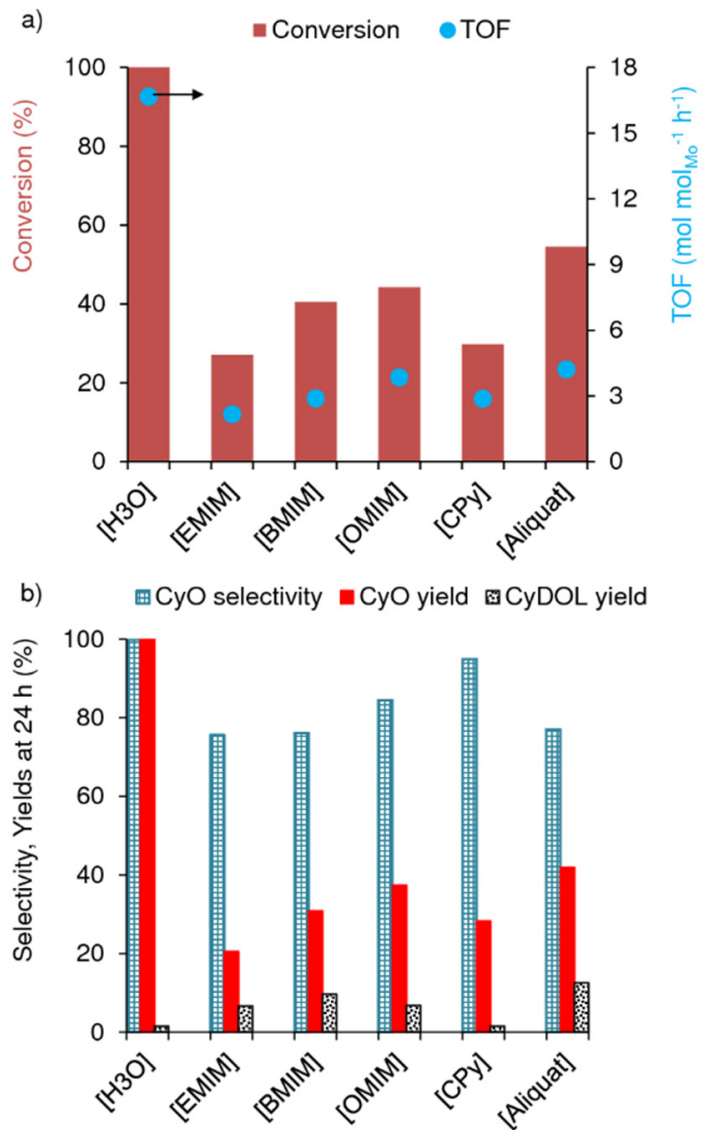

Figure 2. Catalytic epoxidation of Cy with TBHP, in the presence of [Cat] $\left[\mathrm{MoO}\left(\mathrm{O}_{2}\right)_{2}\right.$ (pic)] (only [Cat] is indicated in the abscissa axis for the sake of simplicity): (a) conversion of Cy at $24 \mathrm{~h}$, and turnover frequency (TOF); (b) CyO selectivity, and yields of the epoxide (CyO) and corresponding diol by-product (CyDOL), at $24 \mathrm{~h}$. Reaction conditions: $1 \mathrm{~mol} . \% \mathrm{Mo}$, molar ratio TBHP:Cy $=1.6$, TFT as solvent, $70{ }^{\circ} \mathrm{C}$.

Mechanistic studies for molybdenum-catalysed epoxidation of olefins with alkyl hydroperoxide oxidants corroborate a Lewis acid-base reaction in which the molybdenum compound acts as a Lewis acid and the alkyl hydroperoxide (TBHP) as a Lewis base, leading to an active oxidising species that is involved in the oxygen atom transfer to the olefin, finally giving the epoxide product [65-69]. In the present study, the catalytic epoxidation system [Cat][MoO(O $\left.\mathrm{O}_{2}\right)_{2}$ (pic)]/TBHP is an alternative strategy to that firstly reported by Herbert et al. [2] involving the use of $\left[\mathrm{Bu}_{4} \mathrm{~N}\right]\left[\mathrm{MoO}\left(\mathrm{O}_{2}\right)_{2}\right.$ (pic)] as stoichiometric oxidant (not as catalyst) and $\mathrm{Co}(\mathrm{acac})_{2}$ as catalyst. Later, the same group reported olefin epoxidation using stoichiometric amounts of neutral complexes $\left[\mathrm{MoO}\left(\mathrm{O}_{2}\right)_{2}(\mathrm{~L})_{2}\right](\mathrm{L}=$ pyrazole or 3,5-dimethylpyrazole), with or without a hydroperoxide oxidant, and suggested that the epoxidation reaction mechanism could proceed via Sharpless [65] or Thiel type mechanisms [2,69-71]. In the present study, only $1 \mathrm{~mol} \%$ complex was used, thus if the complex acted as oxidant (and considering one atom of active oxygen per peroxido ligand), it would lead to a maximum Cy conversion of $2 \%$, which is negligible. The catalytic cycle of the system [Cat] $\left[\mathrm{MoO}\left(\mathrm{O}_{2}\right)_{2}(\right.$ pic $\left.)\right] /$ TBHP likely involves a Lewis acid-base type mechanism with TBHP as the oxygen atom source.

The influence of the type of $\mathrm{N}$-containing cation, i.e., imidazolium, pyridinium or ammonium derivatives, on the performance of $[\mathrm{Cat}]\left[\mathrm{MoO}\left(\mathrm{O}_{2}\right)_{2}\right.$ (pic)] type catalysts was studied, using TFT as

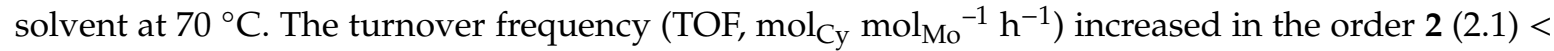
$3(2.9) \approx 5(2.9)<4(3.9) \approx \mathbf{6}(4.2)$ (Figure $2 \mathrm{a}$ ). The parent compound 1 exhibited the highest activity, leading to $100 \% \mathrm{CyO}$ yield at $3 \mathrm{~h}$, compared to $42 \% \mathrm{CyO}$ yield at $24 \mathrm{~h}$ with 1,2-cyclooctanediol (CyDOL) as by-product (13\% yield) for the best-performing catalyst possessing a $\mathrm{N}$-containing cation, 
namely $\mathbf{6}$ (Figure 2b). The catalyst $\mathbf{6}$ was tested using different types of solvents (TFT, DCE, MeCN), which indicated that the most favourable one was TFT. Specifically, Cy conversion at $24 \mathrm{~h}$ increased in the order $\mathrm{MeCN}(27 \%)<\mathrm{DCE}(39 \%)<\mathrm{TFT}(55 \%)$. The poorer results for MeCN as solvent may be partly due to its coordinating ability since, according to the above mechanistic considerations, coordinating solvents may compete with the oxidant molecules for coordination to the molybdenum centre.

To gain insights into the electronic features of the complexes, their electrochemical properties were studied (discussed above). No clear correlation could be established between catalytic activity and the electrochemical properties (Figure 3). The type of cation did not considerably affect the electrochemical properties of the anionic complex. Hence, other factors seem to influence the catalytic performance. Focusing on the set of compounds with $\mathrm{N}$-containing cations, specifically those with imidazolium type cations, it seems that the activity increases with increasing carbon chain length of the alkyl substituent, being highest for $[\mathrm{Cat}]^{+}=[\mathrm{OMIM}]^{+}$. The compound with [Aliquat $]^{+}$, which possesses three $\mathrm{C} 8$ carbon chains, led to the highest Cy conversion at $24 \mathrm{~h}$ (55\%). Possibly, for this set of compounds, longer carbon chains favoured the dissolution of the catalyst in the reaction medium, enhancing the overall reaction rate. On the other hand, the transition state formed via coordination of TBHP to the metal centre (to give an active oxidizing species) may be influenced by the presence of the hydronium cation in the best-performing catalyst $\left[\mathrm{H}_{3} \mathrm{O}\right]\left[\mathrm{MoO}\left(\mathrm{O}_{2}\right)_{2}\right.$ (pic) $]$ (1). For example, the mechanism may involve partial dissociation of the pic ligand and the hydronium cation may influence the protonation of an oxido ligand by TBHP. However, validation of this hypothesis would require more detailed studies, e.g., computational chemistry.

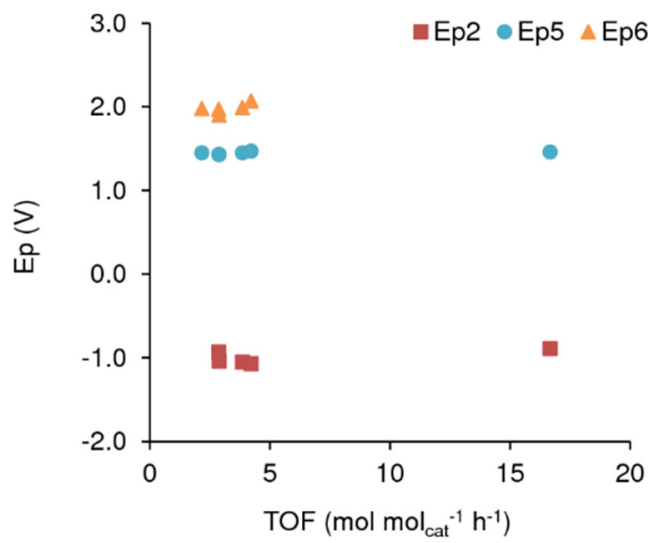

Figure 3. TOF versus $\mathrm{CV}$ results $\left(\mathrm{Ep}_{2}, \mathrm{Ep}_{5}\right.$ and $\left.\mathrm{Ep}_{6}\right)$. Reaction conditions: 1 mol.\% Mo, molar ratio TBHP:Cy $=1.6$, TFT as solvent, $70{ }^{\circ} \mathrm{C}$.

Table 2 compares the results for the prepared catalysts to literature data for $\left[\mathrm{MoO}\left(\mathrm{O}_{2}\right)_{2}(\mathrm{~L})_{\mathrm{n}}\right]$ type complexes tested as catalysts for the Cy/TBHP reaction [35,39,41-45,72-76]. The neutral complex [ $\mathrm{MoO}\left(\mathrm{O}_{2}\right)_{2}\left(2,2^{\prime}\right.$-bipy)] led to $28 \%$ conversion at $24 \mathrm{~h} / 70{ }^{\circ} \mathrm{C}$, in water (entry 23) [35]. In the reaction temperature range $25-55{ }^{\circ} \mathrm{C}$, relatively low $\mathrm{Cy}$ conversions were reached in the presence of the neutral complexes $\left[\mathrm{MoO}\left(\mathrm{O}_{2}\right)_{2}(\mathrm{~L})\right]$ with $\mathrm{L}=$ chiral oxazoline type ligand $(38 \%$ conversion at $22 \mathrm{~h} / 25^{\circ} \mathrm{C}$, in toluene) [73], L = ethyl[3-pyridin-2-yl)-1H-pyrazol-1-yl]acetate (22\% conversion at $24 \mathrm{~h} / 55{ }^{\circ} \mathrm{C}$, in DCE) [42] or L $=2,2^{\prime}$-bipy ( $34 \%$ conversion at $6 \mathrm{~h} / 55^{\circ} \mathrm{C}$, in TFT) [76] (entries $10,19,22)$. In the temperature range $55-75^{\circ} \mathrm{C}$, high $\mathrm{Cy}$ conversions in the range $90-100 \%$ were reached at 6-24 h for neutral complexes $\left[\mathrm{MoO}\left(\mathrm{O}_{2}\right)_{2}(\mathrm{~L})\right]$ with $\mathrm{L}=2$-(2-pyridyl)-benzimidazole [72], 2-[3(5)-pyrazolyl]pyridine [39,74],2-(1-pentyl-3-pyrazolyl)pyridine [75] (using chlorinated organic solvents, entries 9, 18, 21), $\mathrm{L}=4$, 4' -di-tert-butyl-2,2' -bipyridine [35] (using $\mathrm{H}_{2} \mathrm{O}$ as solvent, entry 24), or $\mathrm{L}=$ bis(pyrazolyl)methane) [45] (without solvent, entry 25). The anionic complex $\left[\mathrm{MoO}\left(\mathrm{O}_{2}\right)_{2} \text { (phox) }\right]^{-}$ (the cation was not specified) led to $45 \%$ conversion at $20 \mathrm{~min} / 80^{\circ} \mathrm{C}$ (no solvent) [44].

Overall, it is not trivial to make clear comparisons of the results between different studies due to the different reaction conditions used. Nevertheless, a rough comparison to literature data for 
complexes consisting of neutral or ionic $\left[\mathrm{MoO}\left(\mathrm{O}_{2}\right)_{2}(\mathrm{~L})_{n}\right]$ suggests that $\left[\mathrm{H}_{3} \mathrm{O}\right]\left[\mathrm{MoO}\left(\mathrm{O}_{2}\right)_{2}\right.$ (pic)] possesses relatively good activity for Cy epoxidation with TBHP $\left(82 \% / 100 \%\right.$ CyO yield at $1 \mathrm{~h} / 3 \mathrm{~h}$ reaction, $\left.70{ }^{\circ} \mathrm{C}\right)$.

Table 2. Comparison of the catalytic results of the compounds prepared to literature data for complexes consisting of neutral or ionic $\left[\mathrm{MoO}\left(\mathrm{O}_{2}\right)_{2}(\mathrm{~L})_{\mathrm{n}}\right]$ tested for the model reaction of Cy/TBHP $[35,39,41-45,72-76]$.

\begin{tabular}{|c|c|c|c|c|c|c|c|c|c|}
\hline & Catal ${ }^{[a]}$ & Ox:Cy ${ }^{[b]}$ & $\begin{array}{l}\mathrm{Mo}^{[\mathrm{b}]} \\
(\mathrm{mol} \%)\end{array}$ & Solvent & $\mathrm{T}\left({ }^{\circ} \mathrm{C}\right)^{[\mathrm{c}]}$ & $t(h)[c]$ & $\begin{array}{l}\text { Conversion } \\
(\%)^{[d]}\end{array}$ & $\begin{array}{l}\text { Selectivity } \\
(\%)\end{array}$ & Ref \\
\hline 1 & 1 & 1.52 & 1 & TFT & 70 & $1 / 2 / 3$ & $82 / 93 / 100$ & $100 / 100 / 100$ & This work \\
\hline 2 & 2 & 1.52 & 1 & TFT & 70 & $6 / 24$ & $13 / 27$ & $94 / 76$ & This work \\
\hline 3 & 3 & 1.52 & 1 & TFT & 70 & $6 / 24$ & $17 / 41$ & $82 / 76$ & This work \\
\hline 4 & 4 & 1.52 & 1 & TFT & 70 & $6 / 24$ & $23 / 44$ & $77 / 85$ & This work \\
\hline 5 & 5 & 1.52 & 1 & TFT & 70 & $6 / 24$ & $17 / 30$ & $87 / 95$ & This work \\
\hline 6 & 6 & 1.52 & 1 & TFT & 70 & $6 / 24$ & $25 / 55$ & $84 / 77$ & This work \\
\hline 7 & 6 & 1.52 & 1 & $\mathrm{MeCN}$ & 70 & $6 / 24$ & $5 / 27$ & $100 / 76$ & This work \\
\hline 8 & 6 & 1.52 & 1 & DCE & 70 & $6 / 24$ & $16 / 39$ & $91 / 81$ & This work \\
\hline 9 & {$\left[\mathrm{MoO}\left(\mathrm{O}_{2}\right)_{2}(\mathrm{pbim})\right]$} & 1.53 & 1 & $\mathrm{DCE}$ & 70 & $6 / 24$ & $81 / 98$ & 100 & [72] \\
\hline 10 & {$\left[\mathrm{MoO}\left(\mathrm{O}_{2}\right)_{2}(\mathrm{k} 2-\mathrm{N}, \mathrm{O}-\mathrm{L})_{2}\right]$} & 1.5 & 2.5 & Toluene & 25 & 22 & $15 / 38$ & 100 & [73] \\
\hline 11 & {$\left[\mathrm{MoO}\left(\mathrm{O}_{2}\right)_{2}(\right.$ pzpyR 1$)$} & 1.0 & 0.4 & $\mathrm{CHCl}_{3}$ & 65 & 1 & $\mathrm{TON}^{[\mathrm{f}]}$ & 100 & [74] \\
\hline 12 & {$\left[\mathrm{MoO}\left(\mathrm{O}_{2}\right)_{2}(\right.$ pzpyR2) } & 1.0 & 0.4 & $\mathrm{CHCl}_{3}$ & 65 & 1 & $\mathrm{TON}^{[\mathrm{f}]}$ & 100 & [74] \\
\hline 13 & {$\left[\mathrm{MoO}\left(\mathrm{O}_{2}\right)_{2}(\right.$ pzpyR3) } & 1.0 & 0.4 & $\mathrm{CHCl}_{3}$ & 65 & 1 & $\mathrm{TON}^{[\mathrm{f}]}$ & 100 & [74] \\
\hline 14 & {$\left[\mathrm{MoO}\left(\mathrm{O}_{2}\right)_{2}\right.$ (pzpyR4) } & 1.0 & 0.3 & $\mathrm{CHCl}_{3}$ & 65 & 1 & $\mathrm{TON}^{[\mathrm{f}]}$ & 100 & [74] \\
\hline 15 & {$\left[\mathrm{MoO}\left(\mathrm{O}_{2}\right)_{2}\right.$ (pzpyR5) } & 1.0 & 0.2 & $\mathrm{CHCl}_{3}$ & 65 & 1 & TON $[\mathrm{f}]$ & 100 & [74] \\
\hline 16 & {$\left[\mathrm{MoO}\left(\mathrm{O}_{2}\right)_{2}(\right.$ pzpyR6) } & 1.0 & 0.4 & $\mathrm{CHCl}_{3}$ & 65 & 1 & $\mathrm{TON}^{[\mathrm{f}]}$ & 100 & {$[74]$} \\
\hline 17 & {$\left[\mathrm{MoO}\left(\mathrm{O}_{2}\right)_{2}(\right.$ pzpyR7) } & 1.0 & 0.2 & $\mathrm{CHCl}_{3}$ & 65 & 1 & TON $[f]$ & 100 & {$[74]$} \\
\hline 18 & {$\left[\mathrm{MoO}\left(\mathrm{O}_{2}\right)_{2}(\right.$ pzpy) $]$} & 1.52 & 0.3 & DCE & 75 & 6 & 100 & 100 & [39] \\
\hline 19 & {$\left[\mathrm{MoO}\left(\mathrm{O}_{2}\right)_{2}(\right.$ pypzEA $\left.)\right]$} & 1.52 & 0.1 & DCE & 55 & 24 & 22 & 100 & [42] \\
\hline 20 & {$\left[\mathrm{MoO}\left(\mathrm{O}_{2}\right)_{2}(\right.$ bzpypz $\left.)\right]$} & 1 & 0.5 & $\mathrm{CHCl}_{3}$ & $\mathrm{~nm}[\mathrm{~g}]$ & 6 & 95 & 100 & [41] \\
\hline 21 & {$\left[\mathrm{MoO}\left(\mathrm{O}_{2}\right)_{2}\right.$ (pent-pp)] } & 1.52 & 0.9 & DCE & 55 & 6 & 90 & 100 & [75] \\
\hline 22 & {$\left[\mathrm{MoO}\left(\mathrm{O}_{2}\right)_{2}\left(2,2^{\prime}\right.\right.$-bipy $\left.)\right]$} & 1.5 & 1 & TFT & 55 & 6 & 34 & 100 & [76] \\
\hline 23 & {$\left[\mathrm{MoO}\left(\mathrm{O}_{2}\right)_{2}\left(2,2^{\prime}\right.\right.$-bipy $\left.)\right]$} & 1.53 & 1 & $\mathrm{H}_{2} \mathrm{O}$ & 70 & 24 & 28 & 100 & [35] \\
\hline 24 & {$\left[\mathrm{MoO}\left(\mathrm{O}_{2}\right)_{2}(\mathrm{di}-\mathrm{tBu}\right.$-bipy $\left.)\right]$} & 1.53 & 1 & $\mathrm{H}_{2} \mathrm{O}$ & 70 & 24 & 98 & 100 & [35] \\
\hline 25 & {$\left[\mathrm{MoO}\left(\mathrm{O}_{2}\right)_{2}(\mathrm{BPM})\right.$} & 1.53 & 1 & - & 55 & 6 & 100 & 100 & {$[45]$} \\
\hline 26 & {$[\mathrm{~nm}]\left[\mathrm{MoO}\left(\mathrm{O}_{2}\right)_{2} \text { (phox)] }\right]^{[\mathrm{g}]}$} & 1 & 0.05 & - & 95 & 0.33 & 97 & 100 & [43] \\
\hline 27 & {$[\mathrm{~nm}]\left[\mathrm{MoO}\left(\mathrm{O}_{2}\right)_{2}\right.$ (phox)] $[\mathrm{g}]$} & 1 & 0.05 & - & $80 / 85 / 95$ & 0.33 & $45 / 69 / 99$ & 100 & [44] \\
\hline 28 & {$[\mathrm{~nm}]\left[\mathrm{MoO}\left(\mathrm{O}_{2}\right)_{2}(\mathrm{phox})\right][\mathrm{g}]$} & 1 & 0.05 & DCE & 95 & 0.33 & 98 & 100 & [44] \\
\hline$=$ & $\begin{array}{l}\text { pic }=\text { picolinate; } \mathrm{pl} \\
\text { py }=2-[3(5) \text {-pyrazolyl]p } \\
=\mathrm{CH}_{2} \mathrm{CONHC}{ }_{18} \mathrm{H}_{37} \\
\text { [-pyrazol-3-yl)pyridine] } \\
\text { 4,4'-di-tert-butyl-2,2'-b } \\
\text { dihydro-1,3-oxazine. } \\
\text { Reaction temperature ( } \\
\text { ing the data reported in } \\
\text { pressed as } \text { mol }_{\mathrm{Cy}} \text { mol }_{\mathrm{cat}}\end{array}$ & $\begin{array}{l}\operatorname{mim}= \\
\text { ridine, } \mathrm{R} \\
\text { pypzEA } \\
\text { pente-pp } \\
\text { pyridine; } \\
\text { Ox:Cy (C } \\
\text { and time } \\
\text { he experin } \\
\left.\mathrm{h}^{-1}\right) \text { ) we }\end{array}$ & $\begin{array}{l}\text { (2-pyrid } \\
=\mathrm{H}, \mathrm{R} 2 \\
=\text { ethyl } \\
2-(1-\text { pe } \\
\text { BPM } \\
=\text { TBH } \\
\text { t). }{ }^{[d]} \mathrm{Cc} \\
\text { ntal sect }\end{array}$ & $\begin{array}{l}\mathrm{CH}_{3}, \mathrm{R} 3 \\
\text { 3-pyridin } \\
\text { yl-3-pyro } \\
\text { bis(py } \\
\text { initial } \mathrm{n} \\
\text { version } \\
\text { n and re }\end{array}$ & $\begin{array}{l}\text { dazole; } \\
\mathrm{C}_{4} \mathrm{H}_{9}, \mathrm{R} \\
\text { 2-yl)- } 1 \mathrm{H}- \\
\text { olyl)pyr } \\
\text { zolyl)m } \\
\text { olar ratic } \\
\text { Cy. [e] } \mathrm{S} \\
\text { orted TO }\end{array}$ & $\begin{array}{l}\mathrm{K} 2-\mathrm{N}, \mathrm{O} \\
=\mathrm{C}_{8} \mathrm{H} \\
\text { yrazol- } \\
\text { ine; } 2,2 \\
\text { hane; } \\
\text { and mo } \\
\text { ectivity }\end{array}$ & $\begin{array}{l}2]=\text { chira } \\
\mathrm{R} 5=\mathrm{C}_{8} \mathrm{H}_{37} \\
\text { l]acetate; } \\
\text { ipy }=2,2^{\prime}-\mathrm{b} \\
\text { hox }=2- \\
\text { bdenum } \mathrm{m} \\
\text { CyO. }{ }^{[\mathrm{f}]} \mathrm{Co} \\
\text { eferred in th }\end{array}$ & $\begin{array}{l}\text { oxazoline } \\
6=\mathrm{CH}_{2} \mathrm{CO} \\
\text { oypz }=[2-(1 \\
\text { yridine; di-t } \\
\text {-hydroxyph } \\
\% \text { in relatio } \\
\text { ersions (cal } \\
\text { manuscript }\end{array}$ & $\begin{array}{l}\text { gands; } \\
\mathrm{C}_{2} \mathrm{H}_{5} \\
\text { senzyl- } \\
\text { u-bipy } \\
\text { nyl)-5, } \\
\text { to } \mathrm{Cy} \text {. } \\
\text { ulated } \\
\text { TON, }\end{array}$ \\
\hline
\end{tabular}

Catalyst (1) was further explored using $\mathrm{H}_{2} \mathrm{O}_{2}$ as oxidant and acetonitrile as solvent (forming a single liquid phase), at $70{ }^{\circ} \mathrm{C}$, which led to slower $\mathrm{Cy}$ reaction kinetics, without affecting epoxide selectivity (100\% CyO selectivity): conversion at $1 \mathrm{~h} / 3 \mathrm{~h} / 6 \mathrm{~h}$ was $18 \% / 30 \% / 47 \%$, compared to $82 \% / 100 \%$ conversion at $1 \mathrm{~h} / 3 \mathrm{~h}$ using TBHP as oxidant (the initial molar ratio Mo:Cy:oxidant was the same for the two oxidising systems). Possibly, the type of active species may be different for the two oxidants $[68,70,71,77]$ and/or the presence of coordination solvents (water added together with $\mathrm{H}_{2} \mathrm{O}_{2}$ and acetonitrile) may lead to competition with the reactants in the coordination to the molybdenum centre. A similar trend was reported previously for Mo-catalysed epoxidation systems [78].

The catalytic system of $1 / \mathrm{TBHP}$ was tested with different substrates (cyclododecene and trans-2-octene), at $70{ }^{\circ} \mathrm{C}$ (Table 3). The corresponding epoxides were the main reaction products. The substrate reactivity decreased in the order $\mathrm{Cy}>$ trans-2-octene $>$ cyclododecene. The higher reactivity of $\mathrm{Cy}$ compared to cyclododecene may be partly associated with steric effects (higher steric hindrance for the latter). Nevertheless, a comparative study for the cyclic versus linear C8 substrates suggests that other factors may also be important, such as electronic ones. A higher energy density of the $\mathrm{C}=\mathrm{C}$ double bond may favour the attack of the nucleophilic olefin on an electrophilic oxidising species [79], to give the epoxide product. 
Table 3. Olefin epoxidation with TBHP, in the presence of $\mathbf{1}^{\text {[a] }}$.

\begin{tabular}{cccc}
\hline Substrate & Time (h) & Conv. $^{[\mathbf{b}]} \mathbf{( \% )}$ & Select. $^{\text {[c] }} \mathbf{( \% )}$ \\
\hline cis-Cyclooctene & $1 / 2 / 3$ & $82 / 93 / 100$ & $100 / 100 / 100$ \\
trans-2-Octene & $1 / 3 / 4$ & $35 / 78 / 84$ & $100 / 97 / 95$ \\
Cyclododecene & $1 / 3 / 4$ & $33 / 65 / 71$ & $97 / 95 / 95$ \\
\hline
\end{tabular}

[a] Reaction conditions: initial molar ratio Mo:Olefin:oxidant $=1: 100: 152,1 \mathrm{~mL}$ of cosolvent, $70{ }^{\circ} \mathrm{C}$. ${ }^{[b]}$ Olefin conversion. ${ }^{[c]}$ Epoxide product selectivity. Byproducts included the respective diols.

The higher reactivity of $\mathrm{Cy}$ than cyclododecene may be related with important steric effects in the reaction of the bulkier olefin, as observed in a previous work of some of us [80]. The epoxide selectivity was excellent (100\%) in the case of Cy and very high for the remaining olefins (95-97\%) Table 3.

\section{Conclusions}

Compounds of the general formula $[\mathrm{Cat}]\left[\mathrm{MoO}\left(\mathrm{O}_{2}\right)_{2}(\mathrm{~L})\right]$ with $\mathrm{L}=$ picolinate and $[\mathrm{Cat}]^{+}=[\mathrm{EMIM}]^{+}$, $[\mathrm{BMIM}]^{+},[\mathrm{OMIM}]^{+},\left[\mathrm{C}_{16} \mathrm{Py}\right]^{+}$and $[\text {Aliquat }]^{+}$, were prepared in high yields. The CV and DPV analysis indicated that variation of the cation structure does not significantly affect the electrochemical properties of the complex anion. This is the only catalytic study which follows the studies by Garah et al. $[31,32,34,60]$ for $[\mathrm{Cat}]_{\mathrm{m}}\left[\mathrm{MoO}\left(\mathrm{O}_{2}\right)_{2}(\mathrm{~L})_{\mathrm{n}}\right]$ type complexes as epoxidation catalysts using TBHP as oxidant. The type of cation may influence the catalytic performance. The complex with [Cat $]^{+}$ $=\left[\mathrm{H}_{3} \mathrm{O}\right]^{+}(\mathbf{1})$ was the most effective catalyst with $\mathrm{Cy}$ as substrate and TBHP as oxidant, leading to $100 \%$ epoxide yield at $3 \mathrm{~h}$ reaction, $70{ }^{\circ} \mathrm{C}$. Catalyst (1) was also active for the epoxidation of (linear) trans-2-octene and (bulkier) cyclododecene. A comparative study for $\mathrm{H}_{2} \mathrm{O}_{2}$ or TBHP as oxidant, indicated that the latter was more favorable, enhancing the reaction kinetics. This catalyst is one of the most active complexes consisting of neutral or ionic $\left[\mathrm{MoO}\left(\mathrm{O}_{2}\right)_{2}(\mathrm{~L})_{n}\right]$ reported so far. The cation exchange for an $\mathrm{N}$-containing cation, i.e., imidazolium, pyridinium, or ammonium derivatives, does not necessarily lead to an improvement in catalytic performance, which highlights the favourable simplicity of (1).

Author Contributions: Conceptualization, Ž.P., I.S.G. and L.C.B.; methodology, Ž.P. and L.C.B.; validation, Ž.P. and M.M.A.; investigation, Ž.P., M.M.A., A.S.M. and L.C.; resources, A.A.V. and L.C.B.; writing—original draft preparation, Ž.P. and M.M.A.; writing—review and editing, I.S.G., A.A.V. and L.C.B.; supervision, A.A.V. and L.C.B. The first two authors contributed equally for the manuscript (share in equal parts as first author). All authors have read and agreed to the published version of the manuscript.

Funding: This work was supported by the Associate Laboratory for Green Chemistry-LAQV which is financed by national funds from FCT/MCTES (UID/QUI/50006/2019) and by the Applied Molecular Biosciences Unit-UCIBIO which is financed by national funds from FCT/MCTES (UID/Multi/04378/2019). This work was also developed within the scope of the project CICECO-Aveiro Institute of Materials, UIDB/50011/2020 \& UIDP/50011/2020, financed by national funds through the Portuguese Foundation for Science and Technology/MCTES. The positions held by M.M.A. and Z.P. were funded by national funds (OE), through FCT, I.P., in the scope of the framework contract foreseen in the numbers 4, 5 and 6 of article 23 of the Decree-Law 57/2016 of 29 August, changed by Law $57 / 2017$ of 19 July.

Conflicts of Interest: The authors declare no conflict of interest.

\section{References}

1. Mimoun, H.; Deroch, I.S.; Sajus, L. New molybdenum-6 and Tungsten-6 Peroxy-Complexes. Bull. Soc. Chim. Fr. 1969, 5, 1481-1492.

2. Herbert, M.; Montilla, F.; Álvarez, E.; Galindo, A. New insights into the mechanism of oxodiperoxomolybdenum catalysed olefin epoxidation and the crystal structures of several oxo-peroxo molybdenum complexes. Dalton Trans. 2012, 41, 6942-6956. [CrossRef] [PubMed]

3. Maiti, S.K.; Malik, K.M.A.; Gupta, S.; Chakraborty, S.; Ganguli, A.K.; Mukherjee, A.K.; Bhattacharyya, R. Oxo- and Oxoperoxo-molybdenum(VI) Complexes with Aryl Hydroxamates: Synthesis, Structure, and Catalytic Uses in Highly Efficient, Selective, and Ecologically Benign Peroxidic Epoxidation of Olefins. Inorg. Chem. 2006, 45, 9843-9857. [CrossRef] [PubMed] 
4. Salles, L.; Piquemal, J.-Y.; Thouvenot, R.; Minot, C.; Brégeault, J.-M. Catalytic epoxidation by heteropolyoxoperoxo complexes: From novel precursors or catalysts to a mechanistic approach. J. Mol. Catal. A Chem. 1997, 117, 375-387. [CrossRef]

5. Joergensen, K.A. Transition-metal-catalyzed epoxidations. Chem. Rev. 1989, 89, 431-458. [CrossRef]

6. Deubel, D.V.; Frenking, G.; Gisdakis, P.; Herrmann, W.A.; Rösch, N.; Sundermeyer, J. Olefin Epoxidation with Inorganic Peroxides. Solutions to Four Long-Standing Controversies on the Mechanism of Oxygen Transfer. Acc. Chem. Res. 2004, 37, 645-652. [CrossRef]

7. Deubel, D.V. Ethylene Epoxidation with Tungsten Diperoxo Complexes: Is Relativity the Origin of Reactivity? J. Phys. Chem. A 2001, 105, 4765-4772. [CrossRef]

8. Abednatanzi, S.; Abbasi, A.; Masteri-Farahani, M. Enhanced catalytic activity of nanoporous Cu3(BTC)2 metal-organic framework via immobilization of oxodiperoxo molybdenum complex. New J. Chem. 2015, 39, 5322-5328. [CrossRef]

9. Das, S.; Bhowmick, T.; Punniyamurthy, T.; Dey, D.; Nath, J.; Chaudhuri, M.K. Molybdenum(VI)-peroxo complex catalyzed oxidation of alkylbenzenes with hydrogen peroxide. Tetrahedron Lett. 2003, 44, 4915-4917. [CrossRef]

10. Bandyopadhyay, R.; Biswas, S.; Bhattacharyya, R.; Guha, S.; Mukherjee, A.K. Novel oxo-peroxo molybdenum(VI) complexes incorporating 8-quinolinol: Synthesis, structure and catalytic uses in the environmentally benign and cost-effective oxidation method of methyl benzenes: $\operatorname{Ar}(\mathrm{CH} 3)(n=1,2)$. Chem. Commun. 1999, 17, 1627-1628. [CrossRef]

11. Ballistreri, F.P.; Barbuzzi, E.G.M.; Tomaselli, G.A.; Toscano, R.M. Multiplicity of Reaction Pathways in the Processes of Oxygen Transfer to Secondary Amines by Mo(VI) and W(VI) Peroxo Complexes. J. Org. Chem. 1996, 61, 6381-6387. [CrossRef]

12. Biradar, A.V.; Kotbagi, T.V.; Dongare, M.K.; Umbarkar, S.B. Selective N-oxidation of aromatic amines to nitroso derivatives using a molybdenum acetylide oxo-peroxo complex as catalyst. Tetrahedron Lett. 2008, 49, 3616-3619. [CrossRef]

13. Maiti, S.K.; Banerjee, S.; Mukherjee, A.K.; Abdul Malik, K.M.; Bhattacharyya, R. Oxoperoxo molybdenum(vi) and tungsten(vi) and oxodiperoxo molybdate(vi) and tungstate(vi) complexes with 8-quinolinol: Synthesis, structure and catalytic activity. New J. Chem. 2005, 29, 554-563. [CrossRef]

14. Thiruvengetam, P.; Chakravarthy, R.D.; Chand, D.K. A molybdenum based metallomicellar catalyst for controlled and chemoselective oxidation of activated alcohols in aqueous medium. J. Catal. 2019, 376, 123-133. [CrossRef]

15. Luan, Y.; Wang, G.; Luck, R.L.; Yang, M.; Han, X. Oxidation of Alcohols with Hydrogen Peroxide Catalyzed by Molybdenum(VI)-Peroxo Complex under Solvent-free Conditions. Chem. Lett. 2007, 36, 1236-1237. [CrossRef]

16. Rostamnia, S.; Mohsenzad, F. Nanoarchitecturing of open metal site Cr-MOFs for oxodiperoxo molybdenum complexes $[\mathrm{MoO}(\mathrm{O} 2) 2 @ E n / \mathrm{MIL}-100(\mathrm{Cr})]$ as promising and bifunctional catalyst for selective thioether oxidation. Mol. Catal. 2018, 445, 12-20. [CrossRef]

17. Amini, M.; Bagherzadeh, M.; Atabaki, B.; Derakhshandeh, P.G.; Ellern, A.; Woo, L.K. Molybdenum(VI)-oxodiperoxo complex containing an oxazine ligand: Synthesis, X-ray studies, and catalytic activity. J. Coord. Chem. 2014, 67, 1429-1436. [CrossRef]

18. Carrasco, C.J.; Montilla, F.; Bobadilla, L.; Ivanova, S.; Odriozola, J.A.; Galindo, A. Oxodiperoxomolybdenum complex immobilized onto ionic liquid modified SBA-15 as an effective catalysis for sulfide oxidation to sulfoxides using hydrogen peroxide. Catal. Today 2015, 255, 102-108. [CrossRef]

19. Ballistreri, F.P.; Tomaselli, G.A.; Toscano, R.M.; Conte, V.; Di Furia, F. Application of the thianthrene 5-oxide mechanistic probe to peroxometal complexes. J. Am. Chem. Soc. 1991, 113, 6209-6212. [CrossRef]

20. Bonchio, M.; Conte, V.; Assunta De Conciliis, M.; Di Furia, F.; Ballistreri, F.P.; Tomaselli, G.A.; Toscano, R.M. The Relative Reactivity of Thioethers and Sulfoxides toward Oxygen Transfer Reagents: The Oxidation of Thianthrene 5-Oxide and Related Compounds by MoO5HMPT. J. Org. Chem. 1995, 60, 4475-4480. [CrossRef]

21. Basak, A.; Barlan, A.U.; Yamamoto, H. Catalytic enantioselective oxidation of sulfides and disulfides by a chiral complex of bis-hydroxamic acid and molybdenum. Tetrahedron Asymmetry 2006, 17, 508-511. [CrossRef]

22. Batigalhia, F.; Zaldini-Hernandes, M.; Ferreira, A.; Malvestiti, I.; Cass, Q. Selective and Mild Oxidation of Sulfides to Sulfoxides by Oxodiperoxo Molybdenum Complexes Adsorbed onto Silica Gel. Tetrahedron 2001, 57, 9669-9676. [CrossRef] 
23. Bortolini, O.; Di Furia, F.; Modena, G.; Seraglia, R. Metal catalysis in oxidation by peroxides. Sulfide oxidation and olefin epoxidation by dilute hydrogen peroxide, catalyzed by molybdenum and tungsten derivatives under phase-transfer conditions. J. Org. Chem. 1985, 50, 2688-2690. [CrossRef]

24. Keilen, G.; Benneche, T.; Gaare, K.; Undheim, K. Peroxymolybdenum complexes in sulfide to sulfone oxidations. Acta Chem. Scand. 1992, 46, 867-871. [CrossRef]

25. Khurana, J.M.; Agrawal, A.; Kumar, S. Oxidation of chalcogenides using the peroxo complex of molybdenum $[\mathrm{MoO}(\mathrm{O} 2) 2(\mathrm{H} 2 \mathrm{O})(\mathrm{hmpa})]$, hmpa = hexamethylphosphoramide. J. Braz. Chem. Soc. 2009, 20, 1256-1261. [CrossRef]

26. Burke, A.J. Chiral oxoperoxomolybdenum(VI) complexes for enantioselective olefin epoxidation: Some mechanistic and stereochemical reflections. Coord. Chem. Rev. 2008, 252, 170-175. [CrossRef]

27. Amini, M.; Haghdoost, M.M.; Bagherzadeh, M. Monomeric and dimeric oxido-peroxido tungsten(VI) complexes in catalytic and stoichiometric epoxidation. Coord. Chem. Rev. 2014, 268, 83-100. [CrossRef]

28. Amini, M.; Haghdoost, M.M.; Bagherzadeh, M. Oxido-peroxido molybdenum(VI) complexes in catalytic and stoichiometric oxidations. Coord. Chem. Rev. 2013, 257, 1093-1121. [CrossRef]

29. Dickman, M.H.; Pope, M.T. Peroxo and Superoxo Complexes of Chromium, Molybdenum, and Tungsten. Chem. Rev. 1994, 94, 569-584. [CrossRef]

30. Neves, P.; Gomes, A.C.; Paz, F.A.A.; Valente, A.A.; Gonçalves, I.S.; Pillinger, M. Synthesis, structure and catalytic olefin epoxidation activity of a dinuclear oxo-bridged oxodiperoxomolybdenum(VI) complex containing coordinated 4,4'-bipyridinium. Mol. Catal. 2017, 432, 104-114. [CrossRef]

31. Gharah, N.; Chattopadhyay, B.; Maiti, S.K.; Mukherjee, M. Synthesis and catalytic epoxidation potential of oxodiperoxo molybdenum(VI) complexes with 2-hydroxybenzohydroxamate and 2-hydroxybenzoate: The crystal structure of PPh4[MoO(O2)2 (HBA)]. Transit. Metal Chem. 2010, 35, 531-539. [CrossRef]

32. Gharah, N.; Drew, M.G.B.; Bhattacharyya, R. Synthesis and catalytic epoxidation potentiality of oxodiperoxo molybdenum(VI) complexes with pyridine-2-carboxaldoxime and pyridine-2-carboxylate: The crystal structure of PMePh3[MoO(O2)2(PyCO)]. Transit. Metal Chem. 2009, 34, 549-557. [CrossRef]

33. Maurya, M.R.; Kumar, M.; Sikarwar, S. Polymer-anchored oxoperoxo complexes of vanadium(V), molybdenum(VI) and tungsten(VI) as catalyst for the oxidation of phenol and styrene using hydrogen peroxide as oxidant. React. Funct. Polym. 2006, 66, 808-818. [CrossRef]

34. Gharah, N.; Chakraborty, S.; Mukherjee, A.K.; Bhattacharyya, R. Highly efficient epoxidation method of olefins with hydrogen peroxide as terminal oxidant, bicarbonate as a co-catalyst and oxodiperoxo molybdenum(vi) complex as catalyst. Chem. Commun. 2004, 22, 2630-2632. [CrossRef]

35. Gamelas, C.A.; Gomes, A.C.; Bruno, S.M.; Paz, F.A.A.; Valente, A.A.; Pillinger, M.; Romão, C.C.; Gonçalves, I.S. Molybdenum(vi) catalysts obtained from $\eta 3$-allyl dicarbonyl precursors: Synthesis, characterization and catalytic performance in cyclooctene epoxidation. Dalton Trans. 2012, 41, 3474-3484. [CrossRef]

36. Herbert, M.; Álvarez, E.; Cole-Hamilton, D.J.; Montilla, F.; Galindo, A. Olefin epoxidation by hydrogen peroxide catalysed by molybdenum complexes in ionic liquids and structural characterisation of the proposed intermediate dioxoperoxomolybdenum species. Chem. Commun. 2010, 46, 5933-5935. [CrossRef]

37. Cai, S.-F.; Wang, L.-S.; Fan, C.-L. Catalytic Epoxidation of a Technical Mixture of Methyl Oleate and Methyl Linoleate in Ionic Liquids Using $\mathrm{MoO}(\mathrm{O} 2) 2 \bullet 2 \mathrm{QOH}\left(\mathrm{QOH}=8\right.$-quinilinol) as Catalyst and $\mathrm{NaHCO}_{3}$ as co-Catalyst. Molecules 2009, 14, 2935-2946. [CrossRef]

38. Herbert, M.; Montilla, F.; Galindo, A. Olefin epoxidation in solventless conditions and apolar media catalysed by specialised oxodiperoxomolybdenum complexes. J. Mol. Catal. A Chem. 2011, 338, 111-120. [CrossRef]

39. Amarante, T.R.; Neves, P.; Gomes, A.C.; Nolasco, M.M.; Ribeiro-Claro, P.; Coelho, A.C.; Valente, A.A.; Paz, F.A.A.; Smeets, S.; McCusker, L.B.; et al. Synthesis, Structural Elucidation, and Catalytic Properties in Olefin Epoxidation of the Polymeric Hybrid Material [Mo3O9(2-[3(5)-Pyrazolyl]pyridine)]n. Inorg. Chem. 2014, 53, 2652-2665. [CrossRef]

40. da Palma Carreiro, E.; Yong-En, G.; Burke, A.J. Synthesis, characterisation and reactivity of oxodiperoxo-[2-(1-pyrazolyl)-6-menthylpyridine]molybdenum(VI): The first chiral 2-(1-pyrazole) pyridineoxodiperoxomolybdenum(VI) complex. Inorg. Chim. Acta 2006, 359, 1519-1523. [CrossRef]

41. Hinner, M.J.; Grosche, M.; Herdtweck, E.; Thiel, W.R. A Merrifield Resin Functionalized with Molybdenum Peroxo Complexes: Synthesis and Catalytic Properties. Z. Anorg. Allg. Chem. 2003, 629, 2251-2257. [CrossRef] 
42. Amarante, T.R.; Gomes, A.C.; Neves, P.; Paz, F.A.A.; Valente, A.A.; Pillinger, M.; Gonçalves, I.S. A dinuclear oxo-bridged molybdenum(VI) complex containing a bidentate pyrazolylpyridine ligand: Structure, characterization and catalytic performance for olefin epoxidation. Inorg. Chem. Commun. 2013, 32, 59-63. [CrossRef]

43. Zare, M.; Moradi-Shoeili, Z.; Esmailpour, P.; Akbayrak, S.; Özkar, S. Oxazine containing molybdenum(VI)-oxodiperoxo complex immobilized on SBA-15 as highly active and selective catalyst in the oxidation of alkenes to epoxides under solvent-free conditions. Microporous Mesoporous Mater. 2017, 251, 173-180. [CrossRef]

44. Zare, M.; Moradi-Shoeili, Z. Oxidation of alkenes catalysed by molybdenum(VI)-oxodiperoxo complex anchored on the surface of magnetic nanoparticles under solvent-free conditions. Appl. Organomet. Chem. 2017, 31, e3611. [CrossRef]

45. Figueiredo, S.; Gomes, A.C.; Fernandes, J.A.; Paz, F.A.A.; Lopes, A.D.; Lourenço, J.P.; Pillinger, M.; Gonçalves, I.S. Bis(pyrazolyl)methanetetracarbonyl-molybdenum(0) as precursor to a molybdenum(VI) catalyst for olefin epoxidation. J. Organomet. Chem. 2013, 723, 56-64. [CrossRef]

46. Herbert, M.; Montilla, F.; Galindo, A.; Moyano, R.; Pastor, A.; Álvarez, E. Influence of N-donor bases and the solvent in oxodiperoxomolybdenum catalysed olefin epoxidation with hydrogen peroxide in ionic liquids. Dalton Trans. 2011, 40, 5210-5219. [CrossRef]

47. Shylesh, S.; Schweizer, J.; Demeshko, S.; Schünemann, V.; Ernst, S.; Thiel, W. Nanoparticle Supported, Magnetically Recoverable Oxodiperoxo Molybdenum Complexes: Efficient Catalysts for Selective Epoxidation Reactions. Adv. Synth. Catal. 2009, 351, 1789-1795. [CrossRef]

48. Jia, M.; Seifert, A.; Berger, M.; Giegengack, H.; Schulze, S.; Thiel, W.R. Hybrid Mesoporous Materials with a Uniform Ligand Distribution: Synthesis, Characterization, and Application in Epoxidation Catalysis. Chem. Mater. 2004, 16, 877-882. [CrossRef]

49. Jia, M.; Seifert, A.; Thiel, W.R. Sol-gel synthesis of oxodiperoxo molybdenum-modified organic-inorganic materials for the catalytic epoxidation of cyclooctene. J. Catal. 2004, 221,319-324. [CrossRef]

50. Jia, M.; Seifert, A.; Thiel, W.R. Mesoporous MCM-41 Materials Modified with Oxodiperoxo Molybdenum Complexes: Efficient Catalysts for the Epoxidation of Cyclooctene. Chem. Mater. 2003, 15, 2174-2180. [CrossRef]

51. Jia, M.; Thiel, W.R. Oxodiperoxo molybdenum modified mesoporous MCM-41 materials for the catalytic epoxidation of cyclooctene. Chem. Commun. 2002, 20, 2392-2393. [CrossRef] [PubMed]

52. Dengel, A.C.; Griffith, W.P.; Powell, R.D.; Skapski, A.C. Studies on transition-metal peroxo complexes. Part 7. Molybdenum(VI) and tungsten(VI) carboxylato peroxo complexes, and the X-ray crystal structure of K2[MoO(O2)2(glyc)]2H2O. J. Chem. Soc. Dalton Trans. 1987, 5, 991-995. [CrossRef]

53. Bonchio, M.; Conte, V.; Furia, F.D.; Carofiglio, T.; Magno, F.; Pastore, P. CoII-induced radical oxidations by peroxomolybdenum complexes. J. Chem. Soc. Perkin Trans. 2 1993, 10, 1923-1926. [CrossRef]

54. Campestrini, S.; Di Furia, F.; Novello, F. Oxidation of meso- and d,l-hydrobenzoin by peroxomolybdenum complexes: A mechanistic investigation. J. Mol. Catal. 1993, 78, 159-168. [CrossRef]

55. Campestrini, S.; Di Furia, F.; Modena, G.; Bortolini, O. Metal catalysis in oxidation by peroxides. Part 33. Chemoselective alcohol oxidations by the anionic molybdenum-picolinate $\mathrm{N}$-oxido peroxo complex MoO5PICO. J. Org. Chem. 1990, 55, 3658-3660. [CrossRef]

56. Bortolini, O.; Campestrini, S.; Di Furia, F.; Modena, G.; Valle, G. Metal catalysis in oxidation by peroxides. 27. Anionic molybdenum-picolinate N-oxido-peroxo complex: An effective oxidant of primary and secondary alcohols in nonpolar solvents. J. Org. Chem. 1987, 52, 5467-5469. [CrossRef]

57. Jacobson, S.E.; Muccigrosso, D.A.; Mares, F. Oxidation of alcohols by molybdenum and tungsten peroxo complexes. J. Org. Chem. 1979, 44, 921-924. [CrossRef]

58. Di Furia, F.; Fornasier, R.; Tonellato, U. Catalytic oxidation by a Mo(VI)diperoxo complex as a counter-ion of cationic surfactants in dilute $\mathrm{H} 2 \mathrm{O} 2$ aqueous solutions. J. Mol. Catal. 1983, 19, 81-84. [CrossRef]

59. Campestrini, S.; Conte, V.; Di Furia, F.; Modena, G.; Bortolini, O. Metal catalysis in oxidation by peroxides. 30. Electrophilic oxygen transfer from anionic, coordinatively saturated molybdenum peroxo complexes. J. Org. Chem. 1988, 53, 5721-5724. [CrossRef] 
60. Gharah, N.; Chakraborty, S.; Mukherjee, A.K.; Bhattacharyya, R. Oxoperoxo molybdenum(VI)- and tungsten(VI) complexes with 1-(2'-hydroxyphenyl) ethanone oxime: Synthesis, structure and catalytic uses in the oxidation of olefins, alcohols, sulfides and amines using $\mathrm{H}_{2} \mathrm{O}_{2}$ as a terminal oxidant. Inorg. Chim. Acta 2009, 362, 1089-1100. [CrossRef]

61. Jacobson, S.E.; Tang, R.; Mares, F. Group 6 transition metal peroxo complexes stabilized by polydentate pyridinecarboxylate ligands. Inorg. Chem. 1978, 17, 3055-3063. [CrossRef]

62. Ramos, M.L.; Justino, L.L.G.; Burrows, H.D. Structural considerations and reactivity of peroxocomplexes of V(v), Mo(vi) and W(vi). Dalton Trans. 2011, 40, 4374-4383. [CrossRef] [PubMed]

63. Galiński, M.; Lewandowski, A.; Stępniak, I. Ionic liquids as electrolytes. Electrochim. Acta 2006, 51, 5567-5580. [CrossRef]

64. Matsuyama, S.; Kinugasa, S.; Tanabe, K.; Tamura, T. IR Spectroscopy, Spectral Database for Organic Compounds (SDBS); AIST: Tsukuba, Japan, 2020; Available online: https://sdbs.db.aist.go.jp/sdbs/cgi-bin/direct_frame_ top.cgi (accessed on 1 December 2020).

65. Veiros, L.F.; Prazeres, Â.; Costa, P.J.; Romão, C.C.; Kühn, F.E.; José Calhorda, M. Olefin epoxidation with tert-butyl hydroperoxide catalyzed by MoO2X2L complexes: A DFT mechanistic study. Dalton Trans. 2006, 11, 1383-1389. [CrossRef] [PubMed]

66. Chong, A.O.; Sharpless, K.B. Mechanism of the molybdenum and vanadium catalyzed epoxidation of olefins by alkyl hydroperoxides. J. Org. Chem. 1977, 42, 1587-1590. [CrossRef]

67. Morlot, J.; Uyttebroeck, N.; Agustin, D.; Poli, R. Solvent-Free Epoxidation of Olefins Catalyzed by "[MoO2(SAP)]": A New Mode of tert-Butylhydroperoxide Activation. ChemCatChem 2013, 5, 601-611. [CrossRef]

68. Calhorda, M.; Costa, P. Unveiling the Mechanisms of Catalytic Oxidation Reactions Mediated by Oxo-Molybdenum Complexes: A Computational Overview. Curr. Org. Chem. 2012, 16, 65-72. [CrossRef]

69. Thiel, W.R. Metal catalyzed oxidations. Part 5. Catalytic olefin epoxidation with seven-coordinate oxobisperoxo molybdenum complexes: A mechanistic study. J. Mol. Catal. A Chem. 1997, 117, 449-454. [CrossRef]

70. Thiel, W.R.; Eppinger, J. Molybdenum-Catalyzed Olefin Epoxidation: Ligand Effects. Chem. A Eur. J. 1997, 3, 696-705. [CrossRef]

71. Thiel, W.R.; Priermeier, T. The First Olefin-Substituted Peroxomolybdenum Complex: Insight into a New Mechanism for the Molybdenum-Catalyzed Epoxidation of Olefins. Angew. Chem. Int. Ed. Engl. 1995, 34, 1737-1738. [CrossRef]

72. Neves, P.; Nogueira, L.S.; Gomes, A.C.; Oliveira, T.S.M.; Lopes, A.D.; Valente, A.A.; Gonçalves, I.S.; Pillinger, M. Chemistry and Catalytic Performance of Pyridyl-Benzimidazole Oxidomolybdenum(VI) Compounds in (Bio)Olefin Epoxidation. Eur. J. Inorg. Chem. 2017, 2017, 2617-2627. [CrossRef]

73. Brito, J.A.; Gómez, M.; Muller, G.; Teruel, H.; Clinet, J.-C.; Duñach, E.; Maestro, M.A. Structural Studies of Mono- and Dimetallic MoVI Complexes-A New Mechanistic Contribution in Catalytic Olefin Epoxidation Provided by Oxazoline Ligands. Eur. J. Inorg. Chem. 2004, 21, 4278-4285. [CrossRef]

74. Thiel, W.R.; Angstl, M.; Priermeier, T. Substituierte N,N-Chelat-Liganden-Anwendungen in der Molybdän-katalysierten Olefin-Epoxidation. Chem. Ber. 1994, 127, 2373-2379. [CrossRef]

75. Amarante, T.R.; Neves, P.; Paz, F.A.A.; Valente, A.A.; Pillinger, M.; Gonçalves, I.S. Investigation of a dichlorodioxomolybdenum(vi)-pyrazolylpyridine complex and a hybrid derivative as catalysts in olefin epoxidation. Dalton Trans. 2014, 43, 6059-6069. [CrossRef] [PubMed]

76. Bruno, S.M.; Nogueira, L.S.; Gomes, A.C.; Valente, A.A.; Gonçalves, I.S.; Pillinger, M. High-yield synthesis and catalytic response of chainlike hybrid materials of the $\left[(\mathrm{MoO} 3) \mathrm{m}\left(2,2^{\prime}\right.\right.$-bipyridine $\left.) \mathrm{n}\right]$ family. New J. Chem. 2018, 42, 16483-16492. [CrossRef]

77. Dinoi, C.; Ciclosi, M.; Manoury, E.; Maron, L.; Perrin, L.; Poli, R. Olefin epoxidation by H2O2/MeCN catalysed by cyclopentadienyloxidotungsten(VI) and molybdenum(VI) complexes: Experiments and computations. Chem. Eur. J. 2010, 16, 9572-9584. [CrossRef]

78. Sözen-Aktaş, P.; Manoury, E.; Demirhan, F.; Poli, R. Molybdenum versus Tungsten for the Epoxidation of Cyclooctene Catalyzed by [Cp*2M2O5]. Eur. J. Inorg. Chem. 2013, 15, 2728-2735. [CrossRef] 
79. Di Valentin, C.; Gisdakis, P.; Yudanov, I.V.; Rösch, N. Olefin Epoxidation by Peroxo Complexes of Cr, Mo, and W. A Comparative Density Functional Study. J. Org. Chem. 2000, 65, 2996-3004. [CrossRef]

80. Amarante, T.R.; Antunes, M.M.; Valente, A.A.; Paz, F.A.A.; Pillinger, M.; Gonçalves, I.S. Crystal Structure and Catalytic Behavior in Olefin Epoxidation of a One-Dimensional Tungsten Oxide/Bipyridine Hybrid. Inorg. Chem. 2015, 54, 9690-9703. [CrossRef]

Publisher's Note: MDPI stays neutral with regard to jurisdictional claims in published maps and institutional affiliations.

(C) 2020 by the authors. Licensee MDPI, Basel, Switzerland. This article is an open access article distributed under the terms and conditions of the Creative Commons Attribution (CC BY) license (http://creativecommons.org/licenses/by/4.0/). 